\title{
Bioaerosols and atmospheric ice nuclei in a Mediterranean dryland: Community changes related to rainfall
}

Kai Tang 1,*, Beatriz Sánchez-Parra ${ }^{1,2, *}$, Petya Yordanova ${ }^{1, *}$, Jörn Wehking ${ }^{1, a}$, Anna T. Backes ${ }^{1}$, Daniel A. Pickersgill ${ }^{1}$, Stefanie Maier ${ }^{2}$, Jean Sciare ${ }^{3}$, Ulrich Pöschl ${ }^{1}$, Bettina Weber ${ }^{1,2}$, and Janine Fröhlich-Nowoisky ${ }^{1}$

\author{
${ }^{1}$ Multiphase Chemistry Department, Max Planck Institute for Chemistry, P.O. Box 3060, 55020 Mainz, Germany \\ ${ }^{2}$ Institute of Biology, University of Graz, Holteigasse 6, $8010 \mathrm{Graz}$, Austria \\ ${ }^{3}$ Climate and Atmosphere Research Center, The Cyprus Institute, 2121 Nicosia, Cyprus \\ ${ }^{a}$ now at: HygCen Austria GmbH, Werksgelände 285500 Bischofshofen, Austria \\ *These authors contributed equally to this work.
}

Correspondence: Janine Fröhlich-Nowoisky (j.frohlich@mpic.de)

\begin{abstract}
.
Certain biological particles are highly efficient ice nuclei (IN), but the actual contribution of bioparticles to the pool of atmospheric IN and their relation to precipitation are not well characterized. We investigated the composition of bioaerosols, ice nucleation activity, and the effect of rainfall by metagenomic sequencing and freezing experiments of aerosol samples collected during the INUIT 2016 campaign in a rural dryland on the Eastern Mediterranean island Cyprus. Taxonomic analysis showed community changes related to rainfall. For the rain-affected samples, we found higher read proportions of fungi, in particular of Agaricomycetes, which are a class of fungi actively discharging their spores into the atmosphere in response to humidity changes. In contrast, the read proportions of bacteria were reduced, indicating an effective removal of bacteria by precipitation. Freezing experiments showed that the IN population in the investigated samples was influenced by both rainfall and dust events. For example, filtration and heat treatment of the samples collected during and immediately after rainfall yielded enhanced fractions of heat-sensitive IN in the size ranges larger than $5 \mu \mathrm{m}$ and smaller than $0.1 \mu \mathrm{m}$, which were likely of biological origin (entire bioparticles and soluble macromolecular bio-IN). In contrast, samples collected in periods with dust events were dominated by heat-resistant IN active at lower temperatures, most likely mineral dust. The DNA analysis revealed low numbers of reads related to microorganisms that are known to be IN-active. This may reflect unknown sources of atmospheric bio-IN as well as the presence of cell-free IN macromolecules that do not contain DNA, in particular for sizes $<0.1 \mu \mathrm{m}$. The observed effects of rainfall on the composition of atmospheric bioaerosols and IN may influence the hydrological cycle (bioprecipitation cycle) as well as the health effects of air particulate matter (pathogens, allergens).
\end{abstract}

\section{Introduction}

Primary biological aerosol particles, or short bioaerosols, are a subset of atmospheric aerosol particles directly emitted from the biosphere into the atmopshere. They comprise living and dead microorganisms (e.g., bacteria), dispersal units (e.g., fungal spores, plant pollen), fragments (e.g., plant debris), and viruses (Després et al., 2012; Whon et al., 2012; Fröhlich-Nowoisky 
https://doi.org/10.5194/bg-2021-187

Preprint. Discussion started: 9 August 2021

(c) Author(s) 2021. CC BY 4.0 License.

\section{(c) (i)}

et al., 2016; Smets et al., 2016; Yahya et al., 2019; Pöhlker et al., 2021). Bioaerosols can serve as nuclei for cloud droplets and ice crystals influencing the formation of precipitation, and some of them are important allergens and pathogens (Brown and Hovmøller, 2002; D'Amato et al., 2007; Andreae and Rosenfeld, 2008; Steiner et al., 2015; Müller-Germann et al., 2017; Fröhlich-Nowoisky et al., 2016; Lang-Yona et al., 2018; Huang et al., 2021). The abundance and composition of bioaerosols are determined by local emission sources, meteorological conditions, and long-range transport (Jones and Harrison, 2004; Franzetti et al., 2011; Bowers et al., 2012, 2013; Gandolfi et al., 2013; Cao et al., 2014; Archer et al., 2020).

Rainfall and the associated increase of humidity can lead to increased emission of biological aerosol particles (Heo et al., 2014; Wright et al., 2014; Rathnayake et al., 2017). For example, raindrops hitting leaf or soil surfaces can disperse bacteria and other bioparticles by splashing (Hirst, 1953; Madden, 1997; Gilet and Bourouiba, 2014; Perryman et al., 2014; Kim et al., 2019; Gregory et al., 1959; Joung et al., 2017). Furthermore, the increase of relative humidity can trigger the emission of fungal spores by active discharge mechanisms (Zoberi, 1964; Lacey, 1996; Elbert et al., 2007), and pollen grains can rupture under moist conditions releasing sub-pollen particles (Taylor et al., 2002, 2004; Taylor and Jonsson, 2004; Miguel et al., 2006; Steiner et al., 2015).

The release of bioaerosols, which can serve as cloud condensation nuclei (CCN) or ice nuclei (IN), can in turn influence the evolution of clouds and precipitation, thus closing a feedback cycle known as bioprecipitation (Sands et al., 1982; Möhler et al., 2007; Morris et al., 2014; Steiner et al., 2015; Fröhlich-Nowoisky et al., 2016). Especially over vegetated regions, in marine environments, or under remote conditions, bioparticles might represent a significant fraction of CCN and IN (Andreae and Rosenfeld, 2008; Pöschl et al., 2010; Pöhlker et al., 2012; Burrows et al., 2013; Wilson et al., 2015). As IN of biological origin (bio-IN) can trigger freezing at higher temperatures than mineral IN, they are expected to play a role at cloud temperatures $>-15^{\circ} \mathrm{C}$ (Hoose and Möhler, 2012; Fröhlich-Nowoisky et al., 2016; Coluzza et al., 2017; DeMott and Prenni, 2010).

Increased concentrations of atmospheric IN during and after rainfall have been linked to bioaerosols (e.g., Huffman et al., 2013; Prenni et al., 2013; Schumacher et al., 2013; Tobo et al., 2013; Bigg et al., 2015; Hara et al., 2016b), but the sources and composition of bioparticles, their contribution to the pool of atmospheric IN, and their relation to rainfall are still not well characterized. In this study, we investigated the effects of a short period with rain events on bioaerosol and atmospheric IN composition in a rural dryland. Aerosol samples of boundary layer air were collected on the Mediterranean island Cyprus in April 2016. The taxonomic composition of bioaerosols was determined by shotgun metagenomic sequencing and analysis. Ice nuclei were measured using the high-throughput Twin-plate Ice Nucleation Assay (TINA). Additional filtration and heat treatment experiments were performed to narrow down the IN size ranges and to investigate the heat sensitivity of the IN.

\section{Materials and methods}

\subsection{Aerosol sampling}

Aerosol sampling was performed during the INUIT-BACCHUS-ACTRIS campaign in April 2016 at the Cyprus Atmospheric Observatory, which is a rural background station that operates under the co-operative program for monitoring and evaluation of the long-range transmission of air pollutants in Europe (EMEP) and the European Research Infrastructure for the observation 
https://doi.org/10.5194/bg-2021-187

Preprint. Discussion started: 9 August 2021

(c) Author(s) 2021. CC BY 4.0 License.

\section{(c) (i)}

of Aerosols, Clouds and Trace gases Research Infrastructure (ACTRIS) networks, while at the same time, it is a designated regional Global Atmospheric Watch (GAW) station. The station $\left(35.038692^{\circ} \mathrm{N}, 33.057850^{\circ} \mathrm{E}\right)$ is located close to the villages of Agia Marina ( 630 inhabitants) and Xyliatos ( $\sim 150$ inhabitants) and has an elevation of $532 \mathrm{~m}$ above sea level. The site lies at the northeastern foothills of the Troodos Mountains. The nearest main urban agglomeration is at least $35 \mathrm{~km}$ away. The vegetation at the measurement site is dominated by evergreen scrubs and small trees, blending at higher elevations of the

60 Troodos Mountains into oak and pine forests (Fall, 2012).

Total suspended particle samples were collected on glass fiber filters (Type MN-85/90BF, $150 \mathrm{~mm}$ diameter, retention capacity of $0.5 \mu \mathrm{m}$; Macherey-Nagel GmbH \& Co. KG, Germany) with a High-Volume Aerosol Sampler DHA-80 (DIGITEL Elektronik AG, Hegnau, Switzerland; volumetric flow rate $1000 \mathrm{~L} \mathrm{~min}^{-1}$, sampling time $24 \mathrm{~h}$ ) positioned at the roof top of the Cyprus Atmospheric Observatory station $(\sim 5 \mathrm{~m}$ above the ground). Blank samples were taken at regular intervals $(\sim 3$ day intervals) to detect potential contamination by the aerosol sampler or by filter mounting. For this, filters were mounted in the sampler as for regular sampling, but the sampler was either not turned on at all (mounting blank) or only for $5 \mathrm{~s}$ (start-up blank).

Prior to sampling, all glass fiber filters were pre-baked at $330^{\circ} \mathrm{C}$ for 8 to $10 \mathrm{~h}$ in aluminum bags to remove any biological material. The filter holders were disinfected with Bacillol ${ }^{\circledR} \mathrm{AF}$ (Bode Chemie GmbH, Hamburg, Germany) before use. After sampling, the loaded filters were removed from the filter holders, placed into baked $\left(330^{\circ} \mathrm{C}, 8\right.$ to $\left.10 \mathrm{~h}\right)$ aluminum bags, and stored at $-20^{\circ} \mathrm{C}$, and at $-80^{\circ} \mathrm{C}$ after international transport on dry ice. The aerosol filter samples were cut into 16 equal pieces using a self-made cutting tool, made of gilded sharp blades stuck to a round aluminum frame (140 mm diameter and approximately $1 \mathrm{~cm}$ thickness). Prior to cutting, the cutting tool was sterilized by dipping it into ethanol (96\%) and flaming. The filter sample aliquots were transferred into sterile $50 \mathrm{~mL}$ tubes (Greiner Bio-One, Kremsmünster, Austria) and stored at $-80^{\circ} \mathrm{C}$ until analysis. To avoid contamination, filter handling and processing was carried out under sterile conditions on a clean bench.

Based on the monitored environmental conditions as detailed below, nine aerosol samples were selected for metagenomic sequencing and ice nucleation measurements. A list of the investigated aerosol samples with sampling details is given in Table A1.

\subsection{Meteorological conditions}

80 The meteorological conditions during the sampling campaign in April 2016 were measured at the Cyprus Atmospheric Observatory by the Department of Labour Inspection of Cyprus. The data, comprised of hourly mean values for temperature, relative humidity, rain fall, wind speed, and regulatory mass concentrations for $\mathrm{PM}_{10}$ and $\mathrm{PM}_{2.5}$ were imported into $\mathrm{R}$ version 3.6.3; (R-Development-Core-Team, 2011) and the Coordinated Universal Time (UTC) timestamps were converted to the local Eastern European Time (EET: UTC +2:00).

Figure A1 shows the meteorological conditions and aerosol mass concentrations during collection of the aerosol samples. Temperature and relative humidity (RH) exhibited some variation throughout the campaign. Noticeable is a strong increase of RH on 9 April 2016, followed by a period of high RH (up to $80 \%$ ) and a temperature drop until 14 April 2016 corresponding 
https://doi.org/10.5194/bg-2021-187

Preprint. Discussion started: 9 August 2021

(c) Author(s) 2021. CC BY 4.0 License.

(c) (i)

to samples CY19-CY26. Except for this 5-day period, the daily temperature peaks were in the range of 25 to $30^{\circ} \mathrm{C}$. A period of higher RH was again registered starting on 25 April 2016 (CY48).

April 2016 was mainly dry, with only three rain events. One rain event was registered on 12 April during the last $3 \mathrm{~h}$ of collection of sample CY20, and two small rain events occurred during collection of CY23 on 13 April. Increased PM concentrations, corresponding to dust events (Schrod et al., 2017)), were measured from 9 April to 12 April (CY18 and CY19) and from 15 to 18 April (CY31 and CY32).

\subsection{DNA extraction}

Two filter sample aliquots from opposite sides of each air filter sample were extracted with the ChargeSwitch ${ }^{\mathrm{TM}}$ Forensic DNA Purification Kit (Invitrogen Corporation Thermo Fisher Scientific Inc., Waltham, MA, USA) according to the manufacturer's instructions with the following modifications: incubation at $55^{\circ} \mathrm{C}$ for $60 \mathrm{~min}$ and elution of DNA with $100 \mu \mathrm{L}$ elution buffer. Moreover, the DynaMag ${ }^{\mathrm{TM}}-2$ instead of MagnaRack ${ }^{\mathrm{TM}}$ was used. DNA extracts of the two filter pieces of each sample were pooled and purified with the PowerClean Pro DNA Clean-Up Kit (MO BIO Laboratories, Inc. QIAGEN, Hilden, Germany) according to manufacturer's instructions. To detect potential contamination, four mounting blanks and four start-up blanks were included in the DNA extraction. Additionally, four baked filters were included as filter blanks, and four extractions without any filter served as extraction blanks. DNA concentrations were determined with the DeNovix dsDNA Ultra High Sensitivity Assay (DeNovix Inc. DE, USA) and the Qubit ${ }^{\circledR}$ 3.0 Fluorometer (Thermo Fisher Scientific, USA). DNA was not detected in the mounting, start-up, filter, and extraction blanks, indicating that no contamination occurred during sample handling and extraction.

\subsection{Shotgun metagenome sequencing}

From each DNA extract, one nanogram DNA was sequenced on Illumina HiSeq 3000 (output $2 \times 150$ bp paired-end sequencing reads) and Illumina HiSeq 2500 sequencers (output $2 \times 150$ bp paired-end sequencing reads) at the Max Planck Genome Centre in Cologne, Germany. Illumina TruSeq adapters were used for the sequencing library. The data output per run was $17.5 \mathrm{~GB}$ reads. In total $4.14 \times 10^{8}$ reads were obtained from all samples after quality filtering, with an average of $4.6 \times 10^{7}$ reads per sample.

\subsection{Taxonomic classification}

To identify ribosomal small subunit (SSU; 16S/18S) and large subunit (LSU; 23S/28S) reads and to assign taxonomy and operational taxonomic units (OTUs), the MGnify pipeline 4.1 with MAPseq (1.2.2) and the SILVA database (SSU/LSU version 132) remapped to an eight-level-taxonomy was used (Mitchell et al., 2018; Matias Rodrigues et al., 2017; Quast et al., 2013). In total, $8.41 \times 10^{5} \mathrm{SSU}$ and $1.09 \times 10^{6} \mathrm{LSU}$ reads were obtained with averages of $9.34 \times 10^{4} \mathrm{SSU}$ and $1.21 \times 10^{5} \mathrm{LSU}$ reads per sample. Reads identified as chloroplast and mitochondrial ribosomal gene fragments were excluded from downstream analysis. Preliminary taxonomic analysis displayed unusually high numbers of SSU reads and inconsistencies between SSU and LSU 
https://doi.org/10.5194/bg-2021-187

Preprint. Discussion started: 9 August 2021

(c) Author(s) 2021. CC BY 4.0 License.

\section{(c) (i)}

results for CY26. Analysis of read abundance revealed, that, in contrast to the other samples, the data of CY26 contained a high number of reads starting with sequences of degenerated random $16 \mathrm{~S}$ primers, which are usually used in fingerprinting techniques (Sakallah et al., 1995). Thus, all 16S rRNA reads from sample CY26 were excluded.

All downstream analyses were performed in R version 3.6.3 (R-Development-Core-Team, 2011). The base R functions were used for data processing and plotting. The SSU and LSU files were imported into R using the biomformat package (McMurdie and Paulson, 2019). Additionally, the InterPro matches provided by the MGnify pipeline (Mitchell et al., 2018) were specifically analyzed for viral, allergenic, and bacterial ice nucleating proteins.

\subsection{Freezing experiments and data analysis}

For ice nucleation measurements, aqueous extracts of two pieces of each air filter sample were analyzed using the Twin-plate Ice Nucleation Assay (TINA) (Kunert et al., 2018). The extracts were prepared with pure water, which was obtained from a Barnstead $^{\mathrm{TM}}$ GenPure $^{\mathrm{TM}}$ xCAD Plus water purification system (Thermo Scientific, Braunschweig, Germany), autoclaved at $121^{\circ} \mathrm{C}$ for $20 \mathrm{~min}$, and filtered through a sterile $0.1 \mu \mathrm{m}$ pore diameter polyethersulfone (PES) vacuum filter unit (VWR International, Radnor, PA, USA). For extract preparation, $20 \mathrm{~mL}$ of the pure water were added to each filter piece in sterile $50 \mathrm{~mL}$ tubes (SPL life sciences Co. Ltd, South Korea). The tubes were vortexed at $2700 \mathrm{rpm}$ for $15 \mathrm{~min}$ and another $15 \mathrm{~min}$ upside down (Vortex-Genie 2, Scientific Industries Inc., USA). Afterwards, the aqueous extracts were transferred into new sterile $50 \mathrm{~mL}$ tubes. For IN characterization, $1 \mathrm{~mL}$ aliquots of the aqueous extracts were treated as follows: (i) filtration through a $5 \mu \mathrm{m}$ pore diameter filter (Acrodisc, PES, Pall GmbH, Dreieich, Germany), (ii) filtration through a $0.1 \mu \mathrm{m}$ pore diameter filter (Acrodisc), (iii) incubation at $98^{\circ} \mathrm{C}$ for $1 \mathrm{~h}$, (iv) filtration through a $5 \mu \mathrm{m}$ pore diameter filter and incubation at $98^{\circ} \mathrm{C}$ for $1 \mathrm{~h}$, and (v) filtration through a $0.1 \mu \mathrm{m}$ pore diameter filter and incubation at $98{ }^{\circ} \mathrm{C}$ for $1 \mathrm{~h}$.

Of each untreated and treated aqueous extract, 96 aliquots of $3 \mu \mathrm{L}$ were pipetted by a liquid handling station (epMotion ep5073, Eppendorf, Hamburg, Germany) into 384-well plates (Eppendorf). The plates were placed in the TINA instrument, and, after $1 \mathrm{~min}$ equilibration at $0^{\circ} \mathrm{C}$, they were cooled to $-28^{\circ} \mathrm{C}$ with a continuous cooling rate of $1^{\circ} \mathrm{C}$ min ${ }^{-1}$. Pure water samples (autoclaved and $0.1 \mu \mathrm{m}$ filtered) served as negative controls in the individual experiments. Additionally, aqueous extracts of two filter pieces of one filter blank, one mounting blank, and one start-up blank served as negative controls for the aerosol sampling process (section 2.1). As shown in Fig. B1, the blank samples showed freezing events starting around $-20^{\circ} \mathrm{C}$ with most droplet freezing around $-25^{\circ} \mathrm{C}$. Thus, the observed temperature range for the aerosol samples was 0 to $-20{ }^{\circ} \mathrm{C}$.

The freezing temperature data of the individual measurements were binned into $0.2{ }^{\circ} \mathrm{C}$ intervals, which corresponds to the temperature uncertainty of the measurement (Kunert et al., 2018). For each aerosol sample, the data of the 96 droplets of the two filter pieces were combined to 192 droplets for further calculations. All calculations and plotting was performed with $\mathrm{R}$ version 3.6.3 (R-Development-Core-Team, 2011). The fraction of frozen droplets $\left(f_{\text {ice }}\right)$, the cumulative number of IN $\left(N_{\mathrm{v}}\right)$ per liter of air, and corresponding errors were calculated as described in Vali (1971) and Kunert et al. (2018). 
https://doi.org/10.5194/bg-2021-187

Preprint. Discussion started: 9 August 2021

(c) Author(s) 2021. CC BY 4.0 License.

\section{Results and Discussion}

\subsection{Overall community composition and community changes}

The composition of the airborne community was determined by taxonomic assignment of ribosomal RNA gene SSU (small subunit) and LSU (large subunit) reads. In total, we detected 3000 operational taxonomic units (OTUs) for SSU and 4167 OTUs for LSU reads. Note, that the SSU OTUs do not include data from sample CY26 (see section 2.5). The obtained OTUs, however, can be seen as lower estimates of species richness, as MGnify assigns OTUs based on a reference database to different taxonomic levels. This leads to numerous OTUs at higher taxonomic levels, which comprise reads from multiple species that cannot be identified to lower taxonomic levels. Thus, for downstream analysis and inter-sample comparison, read proportions were used.

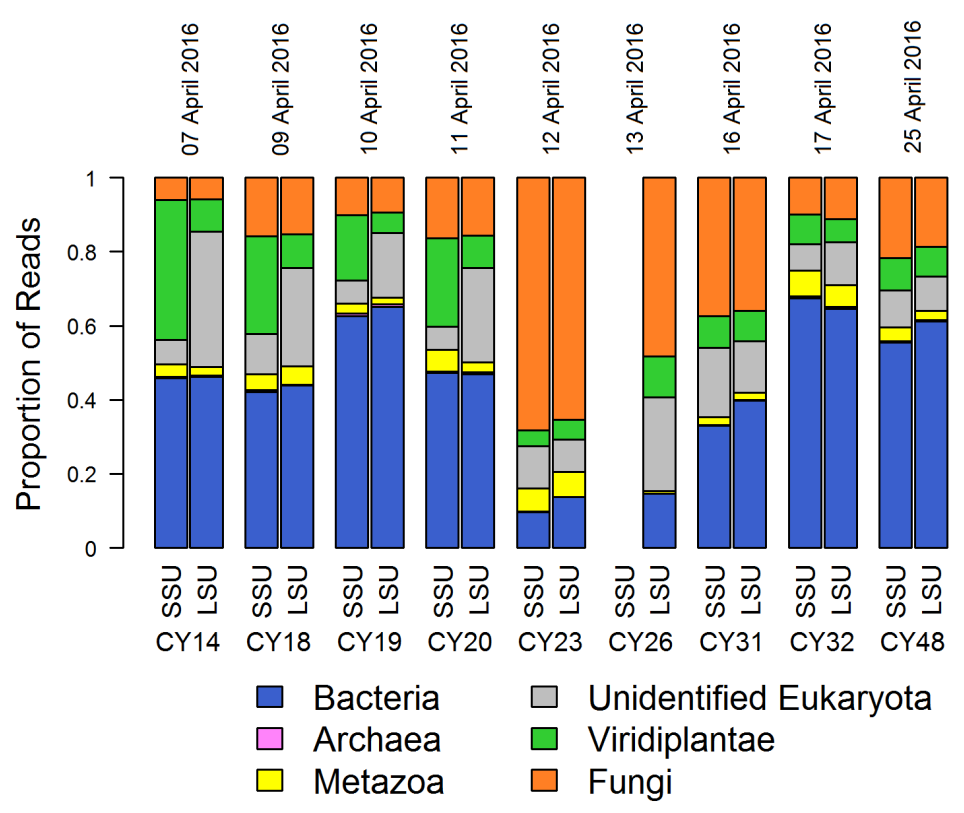

Figure 1. Taxonomic composition. Proportions of SSU and LSU reads assigned to different domains (Bacteria, Archaea, Unidentified Eukaryota) and kingdoms (Metazoa, Viridiplantae, Fungi) for all aerosol samples. SSU reads of CY26 were excluded because of a contamination by $16 \mathrm{~S}$ rRNA gene amplicon sequences. Eukaryota reads, which were not assigned to a kingdom or not further classified, were grouped in "Unidentified Eukaryota". The proportion of Archaea reads was $<1 \%$ for all samples.

Figure 1 shows the read proportions and taxonomic assignments on domain and kingdom level for the individual samples. The taxonomic composition, in particular the read proportion of fungi and bacteria, changed with sample CY23, indicating a change of the airborne community. Sample CY23 was collected after a $3 \mathrm{~h}$ rain event, which corresponds to the collection end of CY20 (Fig. A1). Moreover, two additional rain events occurred during sampling of CY23. This sample shows the 
https://doi.org/10.5194/bg-2021-187

Preprint. Discussion started: 9 August 2021

(c) Author(s) 2021. CC BY 4.0 License.

\section{(c) (i)}

highest proportion of fungal reads $(>60 \%)$ and lowest read proportion of Bacteria $(<20 \%)$ and Viridiplantae $(<10 \%)$. Samples collected up to four days after the rain events (CY26 and CY31) also show higher proportions of fungal reads (up to $50 \%$ ) and lower read proportions for Bacteria and Viridiplantae than the other samples. Metazoa and Archaea read proportions were $<7 \%$ and $<1 \%$, respectively, in all samples (Fig. 1) .

The high proportion of fungal reads in CY23 may result from increased concentrations of fungal spores following rainfall, as many fungal spores are dispersed by rain splash, rain tap and puff, or by other spore discharge mechanisms that require water (e.g., Hirst, 1953; Hirst and Stedman, 1963; Gregory et al., 1959; Lacey, 1996; Jones and Harrison, 2004; Crandall and Gilbert, 2017; Kauserud et al., 2005; Kaygusuz and Faruk Çolak, 2017). Bacteria are often associated with larger particles such as soil dust and plant fragments or form aggregates with each other (Shaffer and Lighthart, 1997; Polymenakou et al., 2008; Reche et al., 2018). As larger particles are more efficiently removed by precipitation than smaller particles, because the latter tend to follow the air stream around the raindrops (Pranesha and Kamra, 1997; Seinfeld and Pandis, 2016), an efficient washout is assumed for bacteria and larger particles. This facilitates the return of airborne bacteria and other biological particles to the Earth's surface as well as deposition in new habitats (Peter et al., 2014; Reche et al., 2018), which possibly explains the reduced read proportions for Bacteria, Viridiplantae, and Unidentified Eukaryota in samples CY23 and CY26.

Figure 1 also shows for the individual samples, that the proportions of SSU and LSU reads assigned to Archaea, Bacteria, Fungi, and Metazoa are comparable, indicating that both genes can be used as representative markers for these groups. In contrast, Viridiplantae and Unidentified Eukaryota show differences in the SSU and LSU read proportions in samples CY14CY20 and more equal read proportions in all other samples. This indicates a change of the airborne community due to the rain events and a lack of plant LSU sequences in the SILVA reference database.

Unlike Pro- and Eukaryotes, for which ribosomal RNA genes can be used for identification, viruses do not contain common genetic markers (Edwards and Rohwer, 2005). Analysis of the InterPro matches, however, revealed the presence of various double and single stranded DNA and RNA viruses in the aerosol samples. Of the virus-related InterPro matches $\sim 44 \%$ were assigned to viruses, which infect bacteria and archaea (e.g., Siphoviridae, Podoviridae, Myoviridae, and Microviridae) and cover $\sim 80 \%$ of the reads that were assigned to virus-related matches. Viruses infecting animals and humans (e.g., Adenoviridae, Baculoviridae, Flaviviridae, Herpesviridae, Poxviridae) exhibited also $\sim 44 \%$ of the matches corresponding to $\sim 4 \%$ of reads. Plant viruses such as Geminiviridae, Caulimoviridae, and Potyviridae were less abundant with $\sim 7 \%$ of the matches and $<1 \%$ of reads. The remaining $\sim 4 \%$ of the virus-related InterPro matches ( $\sim 15 \%$ reads) could either not be assigned to hosts or were from fungi and amoeba infecting viruses. The detection of RNA viruses (e.g., Flaviviridae, Reoviridae, Retroviridae) can be explained by the integration of these viruses into the genomes of their host cells and their persistence as proviruses (Edwards and Rohwer, 2005).

\subsubsection{Composition and community changes of Fungi, Viridiplantae, and Metazoa}

The composition and community changes of Fungi, Viridiplantae, and Metazoa were further analyzed on class level. Figure 2 shows, that most fungal reads could be attributed to different classes and phyla of Ascomycota and Basidiomycota. Large fractions of Ascomycota reads (up to $40 \%$ ) could not be attributed to any Ascomycota class. All samples show higher read 
Fungi
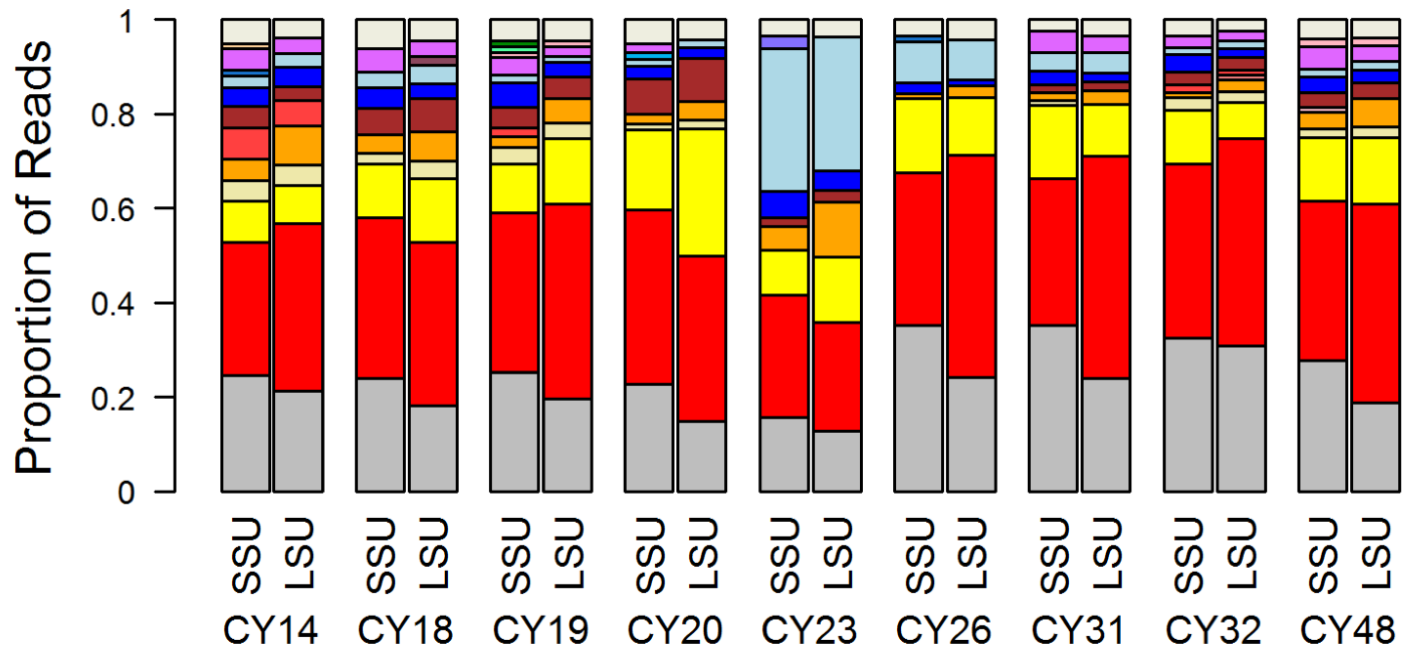

CY20

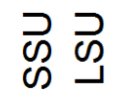

के क

के के

๗ ๘

$\mathrm{CY} 23$

CY26

CY31

CY32

CY48

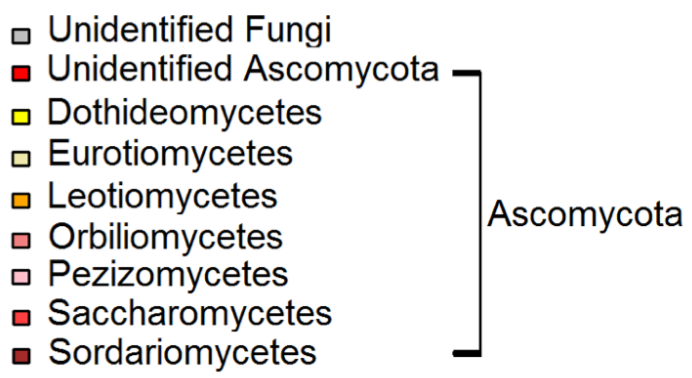

- Unidentified Basidiomycota $\square$ Agaricomycetes 口 Agaricostilbomycetes - Malasseziomycetes

- Microbotryomycetes

a Pucciniomycetes

口 Tremellomycetes

$\square$ Ustilaginomycetes

口 Chytridiomycetes

- Unidentified Mucoromycota

口 Entomophthoromycetes

口 Classes $<1 \%$ Reads 
Viridiplantae

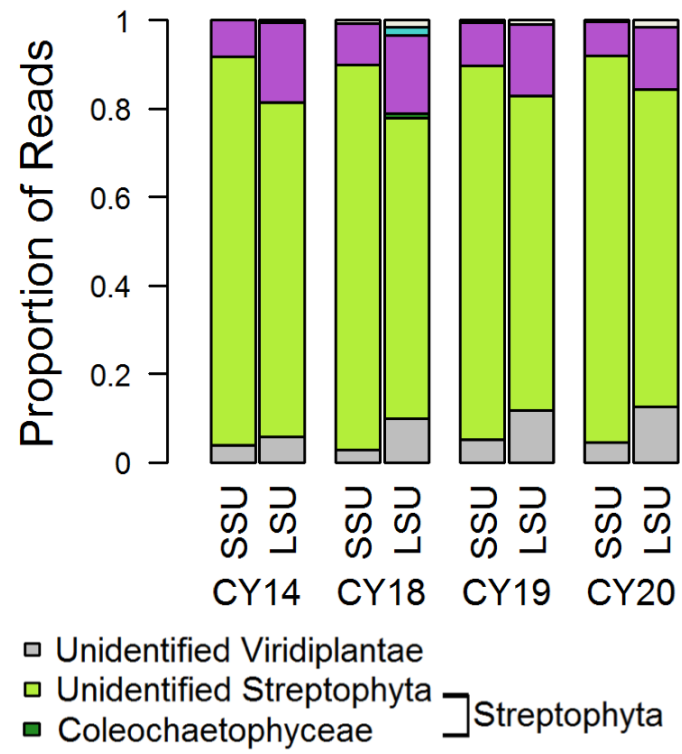

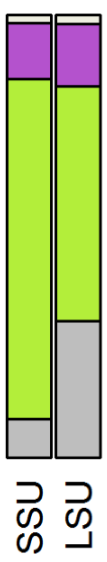
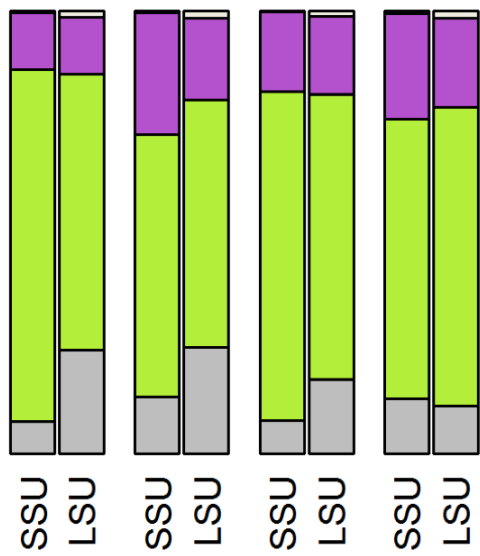

๑

๑

๑

CY23 CY26 $\quad$ CY31 CY32 CY48

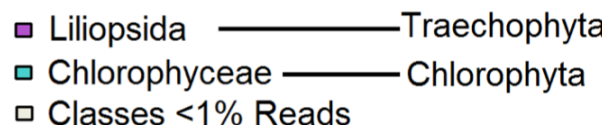

Figure 3. Taxonomic composition of Viridiplantae. Taxonomic classification and proportion of SSU and LSU reads of Viridiplantae at class level.

include land plants and green algae. Between $\sim 8 \%$ and $\sim 28 \%$ of the sample reads were assigned to the class Liliopsida of the Tracheophyta (vascular plants), which comprises lilies, grasses, palms, orchids, and other monocotyledon plants. Samples CY23, CY26, CY31, and CY32 show higher differences in SSU and LSU proportions for Unidentified Viridiplantae than the other samples. Although the limited taxonomic classification does not allow specific discussion, this change of proportions suggests a community change of plant-derived aerosol particles, which can be pollen, moss and fern spores, achene fibers, bark, seeds, algae or fragments like leaf tissues. Pollen, however, are suggested to be the most abundant plant bioaerosols in the atmosphere (Rittenour et al., 2012). The effects of precipitation on pollen concentrations depend primarily on rainfall intensity. While decreased pollen concentrations are associated with more intensive rain events of at least $5 \mathrm{~mm} \mathrm{~h}^{-1}$ (Ribeiro et al., 2003; Rathnayake et al., 2017; Kluska et al., 2020), increased pollen concentrations have been measured immediately before and during rainfall (Puls and Von Wahl, 1991; Kluska et al., 2020). The pollen emission at the onset of rain can be caused by rain drops hitting the stamina of the flowers, which are ready for pollen emission (Puls and Von Wahl, 1991).

As various airborne pollen species are important allergens, the InterPro matches were analyzed for allergenic protein encoding-reads. As detailed in Table C1, twelve possible allergen types were found; all from plants that are common in Cyprus. The most abundant allergens were Amb allergen type, Lol p 1, Bet v 1 type, and Par j 1/2. The Amb allergen type was found in all samples. Amb a-type allergens are major allergens in pollen of ragweed (Ambrosia artemisiifolia, Asteraceae) and Cupressaceae trees (e.g., Mediterranean cypress, mountain cedar), which are abundant in Cyprus (Wolf et al., 2017; Gucel et al., 2013). 
Metazoa
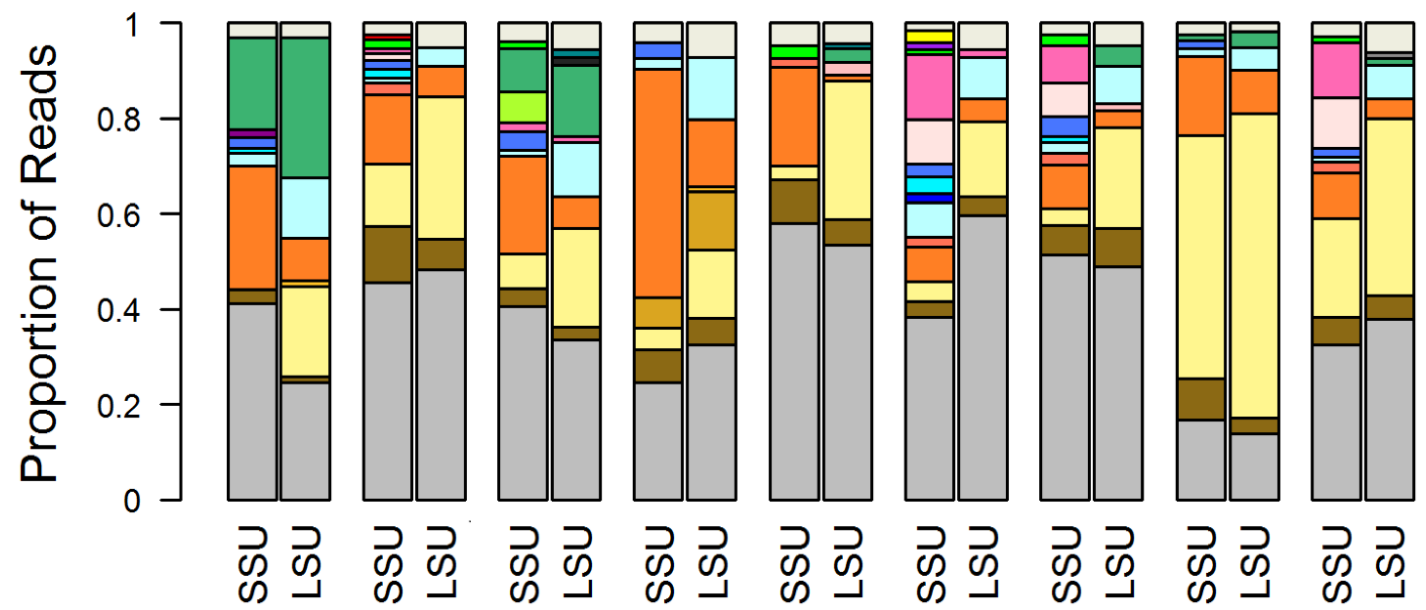

\section{CY14 CY18}

CY19

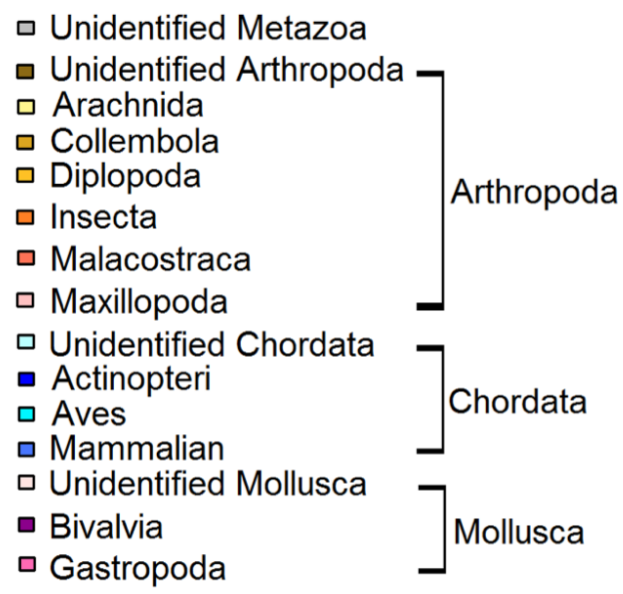

$\square$ Unidentified Nematoda

- Chromadorea

- Enoplea

- Unidentified Platyhelmintes

- Unidentified Annelida

$\square$ Polychaeta

๑ ๙

๘

œ

CY31

CY32

CY48

- Unidentified Cnidaria

- Unidentified Hemichordata

- Unidentified Kinorhyncha

$\square$ Classes $<1 \%$ Reads

Figure 4. Taxonomic composition of Metazoa. Taxonomic classification and proportion of SSU and LSU reads of Metazoa at class level.

The allergen Lol p 1 was found in all samples, except CY19. Lol p 1 is the major allergen of the perennial ryegrass (Lolium perenne, Poaceae), which is common in Cyprus and flowers in spring time (Gucel et al., 2013; Herridge et al., 2021), which was the period of sampling. The Bet v 1-type allergens can be found in members of various plant families such as Betulaceae, Fabaceae, and Rosaceae, which are all common in Cyprus. Samples CY26 and CY48 had with 63 and 20, respectively, higher read counts for Bet v 1-type allergens than all other samples (0-9 reads). The allergens Parj 1/2 from Parietaria judaica exhibited the highest read counts (154) in CY31. Parietaria judaica, a weed of the Urticaceae family and found throughout Cyprus, has a flowering time in spring and autumn and is one of the most important allergens in the Mediterranean area (Colombo et al., 2003; Gucel et al., 2013; Ozturk et al., 2013; Ciprandi et al., 2018). The detected plant allergens allow an additional insight 
https://doi.org/10.5194/bg-2021-187

Preprint. Discussion started: 9 August 2021

(c) Author(s) 2021. CC BY 4.0 License.

(c) (i)

into the origin of the airborne plant particles to the taxonomic analysis of ribosomal reads, but show no clear trends with regard to rain.

Metazoa show a diverse picture on class level with high proportions of up to $60 \%$ of unidentified reads as well as differences in the proportions of SSU and LSU reads (Fig. 4). The identified metazoan classes comprised microbial metazoa (e.g., nematodes (Bik, 2019)) and larger organisms (e.g., insects, spiders, snails). The analysis of the InterPro matches revealed reads encoding for allergens mainly from wasps (Ves m 5/Ves v 5/Ves 5 type) and bees (Api m 3) but also from mites (e.g., Derf 7), nematodes (ABA 1), and mammals (e.g., Fel d 1) as listed in Table C1. All samples show a high proportion of reads assigned to Insecta and Arachnida (includes spiders and mites) and matches to their allergens (Fig. 4, Table C1). Two samples (CY14 and CY19) additionally show larger proportions of nematode reads and matches for nematode allergens. Nematodes are abundant in soil and aquatic environments or can be parasites in plants or animals (Seesao et al., 2017). They can be readily dispersed by the wind as living organisms or resting states, which they produce to survive unfavorable conditions such as dehydration (Nkem et al., 2006; Vanschoenwinkel et al., 2008; Carroll and Viglierchio, 1981; Ptatscheck et al., 2018). The higher read proportions for Gastropoda (snails and slugs) in samples CY26, CY31, and CY48 might be explained by the presence of tissue or skin fragments in the air, due to their dispersal or transport by birds during the nesting phase (Pearce et al., 2010; Shikov and Vinogradov, 2013).

\subsubsection{Composition and community changes of Bacteria and Archaea}

Figure 5 shows the taxonomic composition of Bacteria on class level, which is a typical composition of bacterial communities in air (e.g., Tong and Lighthart, 2000; Bowers et al., 2011; Jeon et al., 2011; Bowers et al., 2012; Robertson et al., 2013; Smith et al., 2013; Yooseph et al., 2013; Jang et al., 2018; Mescioglu et al., 2019). Large proportions of reads were assigned to the Actinobacteria and Firmicutes. At a closer look, the Firmicutes were the dominating prokaryotic phylum, except in sample CY23 and CY26. Taxa within the Firmicutes might be linked to anthropogenic influences, as they are commonly found in soil and in the human gut microbiome (Kho and Lal, 2018; Almeida et al., 2019).

Interestingly, for samples CY23 and CY26, the proportion of Unidentified Bacteria reads is with 40 to $50 \%$ more than twice as high as for all other samples $(<20 \%)$. This might indicate that, for example, soil bacteria were emitted and aerosolized by the impact of raindrops on soil (Joung et al., 2017). The emitted bacterial taxa, however, were not represented in the reference database and remained unidentified. Overall, the results are consistent with the findings of Zhen et al. (2017), who reported temporary shifts of the airborne bacterial community depending on rain intensity, but did not further specify the community structure.

Figure 6 shows that most archaea reads were assigned to the Euryarchaeota, and a small proportion was assigned to the Thaumarchaeota. Similar to bacteria, high proportions of up to $50 \%$ of unidentified reads for samples CY23 and CY26 might indicate some emission of archaea by the impact of rain drops on soil or water surfaces. Within the Euryarchaeota, Halobacteria reads dominated. Halobacteria belong to the extreme halophilic Archaea, which can be found in hypersaline environments (>10\% salt up to saturation) such as salt lakes or saline sediments (Grant and Ross, 1986; Fendrihan et al., 2007; Oren, 2014). 


\section{Bacteria}
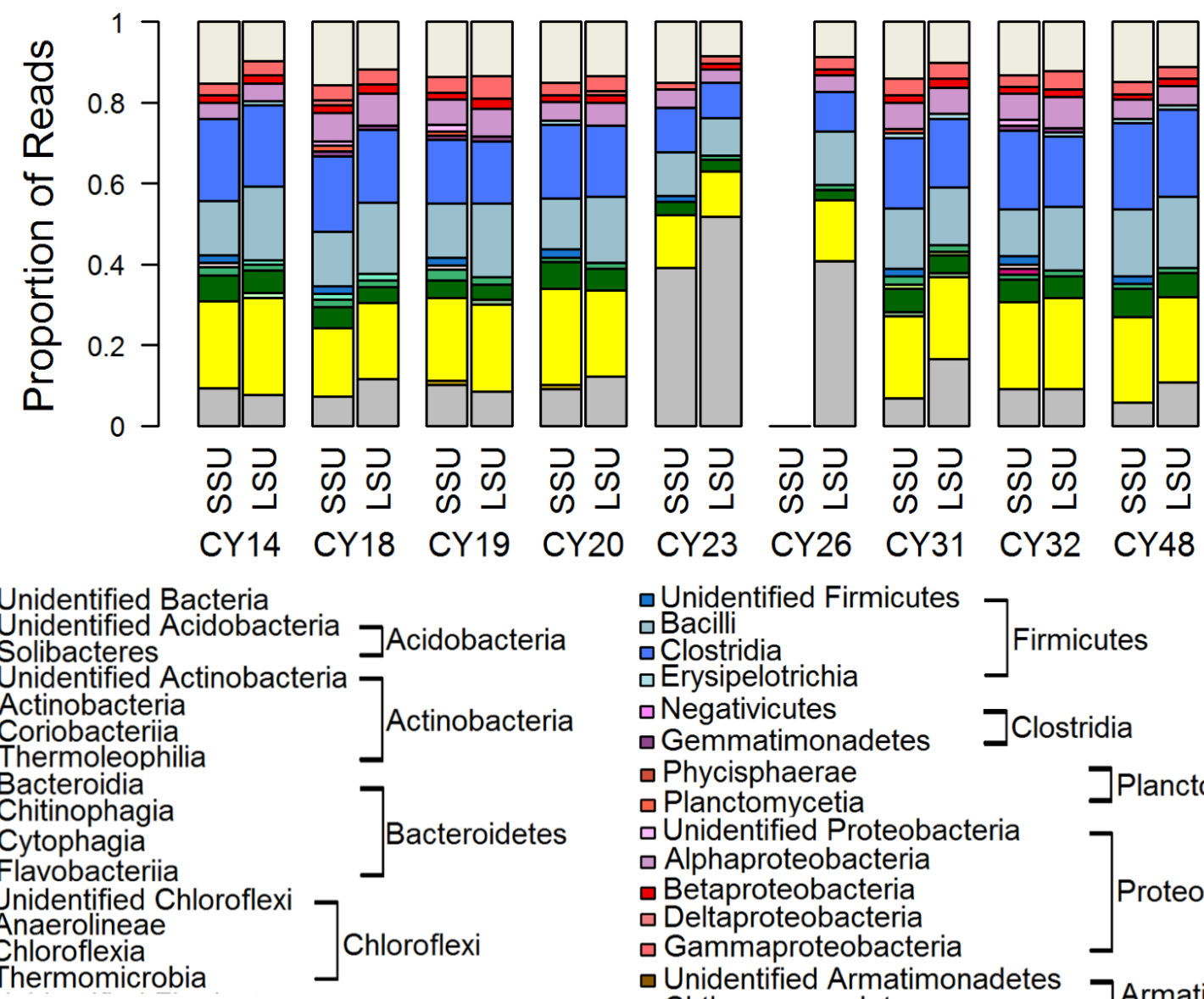

$\mathrm{CY} 23$

CY26

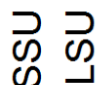

के Ф)

के थे

- Unidentified Firmicutes

a Bacilli

$\square$ Clostridia

口Erysipelotrichia

$\square$ Negativicutes

- Gemmatimonadetes

- Phycisphaerae

口Planctomycetia

a Unidentified Proteobacteria

$\square$ Alphaproteobacteria

- Betaproteobacteria

$\square$ Deltaproteobacteria

- Gammaproteobacteria

- Unidentified Armatimonadetes

$\square$ Chthonomonadetes

$\square$ Classes $<1 \%$ Reads

Firmicutes

Jclostridia

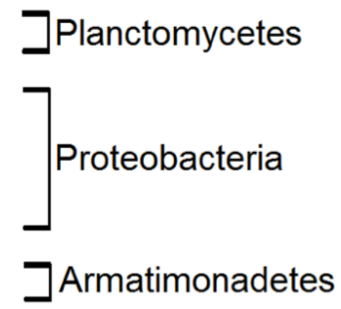

Figure 5. Taxonomic composition of Bacteria. Taxonomic classification and proportion of SSU and LSU reads of Bacteria at class level. SSU reads of CY26 were excluded because of a contamination by $16 \mathrm{~S}$ rRNA gene amplicon sequences.

the detection of methanogens indicates possible anthropogenic influences, as methanogens are not only found in terrestrial and aquatic environments but also in the intestines of larger organisms (Liu and Whitman, 2008; Söllinger and Urich, 2019). Thus, they might stem from the animal waste treatment company in Cyprus, which is close to the station, or from waste water possibly at sewage treatment plants, or marine pollution by hotels or boats. Moreover, airborne Methanobacteria have been found during fertilisation periods (Fröhlich-Nowoisky et al., 2014; Wehking et al., 2018). 
Archaea
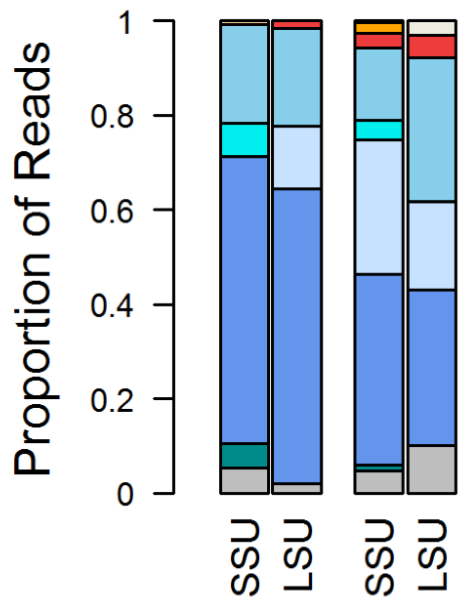

CY14

ㅁ Unidentified Archaea

- Unidentified Euryarchaeota

- Halobacteria

- Methanobacteria

ㅁ Methanomicrobia

ㅁ Thermoplasmata
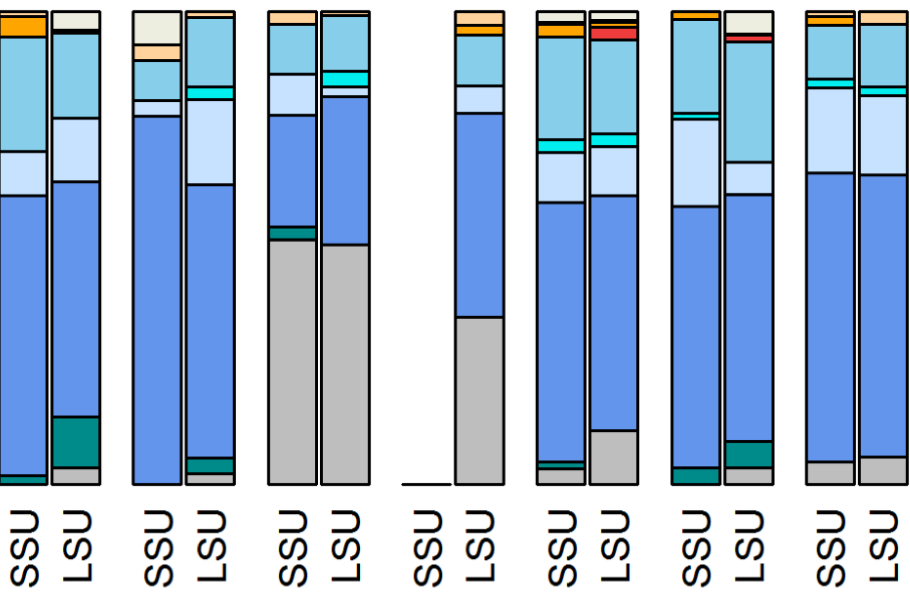

क्ञ

Ф ऽ

๑ ऽ

๑ ऽ

๑ ऽ

๑ ऽ

CY23 CY26

CY31

CY32

CY48

- Unidentified Crenarchaeota

- Unidentified Thaumarchaeota

$\square$ Nitrososphaeria

Thaumarchaeota

\section{Euryarchaeota $\square$ Classes $<1 \%$ Reads}

Figure 6. Taxonomic composition of Archaea. Taxonomic classification and proportion of SSU and LSU reads of Archaea at class level.

\subsection{Ice nucleation activity}

Figure 7 provides an overview of the freezing abilities for the individual samples. Figure 7a shows the fraction of frozen droplets, Fig. $7 \mathrm{~b}$ shows the median temperatures $T_{50}$ (i.e., the temperature at which $50 \%$ of the droplets were frozen), and Fig. 7c shows the ice nuclei (IN) concentrations calculated per liter volume of sampled air (from the data shown in Fig. 7a). The individual samples initiated freezing between $-6.3^{\circ} \mathrm{C}$ and $-11.3^{\circ} \mathrm{C}$. The frozen fraction curves show differences in shapes and slopes as well as different $T_{50}$ values. The curve of sample CY23, which was collected after and during the rain events, approximates a straight line with $T_{50}=-16.7^{\circ} \mathrm{C}$. Contrastingly, the samples CY26-CY32, which were collected after the rain events, show all a similar convex curve shape and higher median freezing temperatures $\left(T_{50}=-13.9^{\circ} \mathrm{C}\right.$ to $\left.-15.5^{\circ} \mathrm{C}\right)$. All other samples, including sample CY48, which was collected 13 days after the last rain event, show concave curves and lower $T_{50}$ values $\left(-17.3^{\circ} \mathrm{C}\right.$ to $\left.-18.3^{\circ} \mathrm{C}\right)$.

Figure $7 \mathrm{c}$ shows that the individual samples differ in their IN concentrations at given temperatures. For example, at $-15^{\circ} \mathrm{C}$, between $10^{-1}$ and $10^{-2}$ IN per liter of sampled air were found for the investigated samples. Overall, the obtained IN concentrations span about two orders of magnitude for temperatures $>-15^{\circ} \mathrm{C}$ and about one order of magnitude for temperatures 
https://doi.org/10.5194/bg-2021-187

Preprint. Discussion started: 9 August 2021

(c) Author(s) 2021. CC BY 4.0 License.

(a)

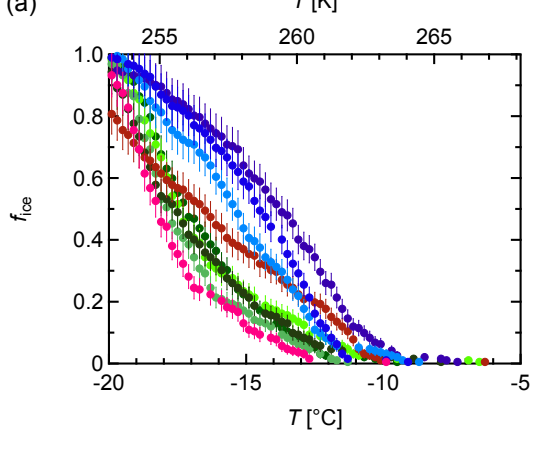

(b)

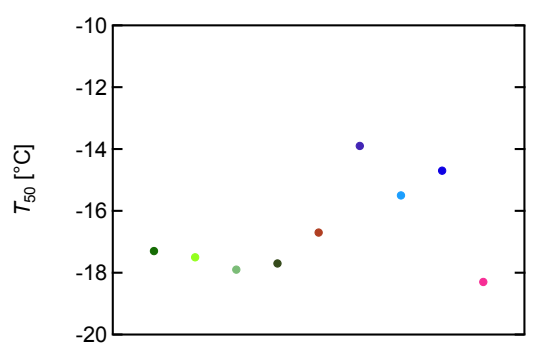

(c)

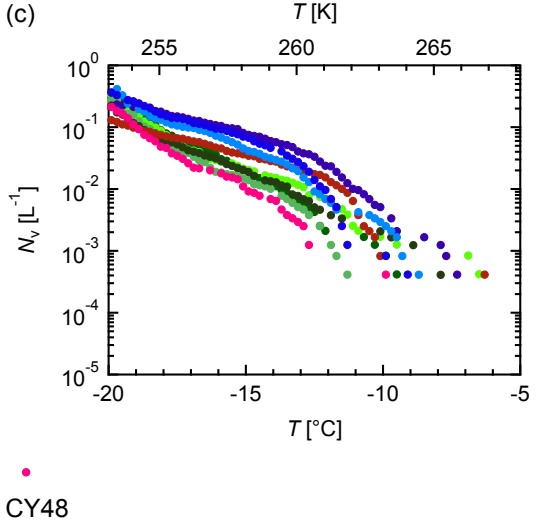

Figure 7. Ice nucleation activity. Fraction of frozen droplets $\left(f_{\text {ice }}\right)$ (a) and cumulative number of IN $\left(N_{\mathrm{v}}\right)$ per liter of air (b) vs. temperature $(T)$ for all aerosol samples. The colors represent individual samples; the error bars were calculated using the counting error and the Gaussian error propagation.

$<-15^{\circ} \mathrm{C}$. These results are in good agreement with Gong et al. (2019), who reported IN concentrations in the same order of magnitude for samples collected in Cyprus in April 2017.

The results indicate heterogeneity of the IN compositions in the samples. Higher initial freezing temperatures and $T_{50}$ values can be an indication for the presence of bio-IN, as many bio-IN are known to nucleate at temperatures $>-15^{\circ} \mathrm{C}$ while mineral IN dominate at $<-15^{\circ} \mathrm{C}$ (e.g., Maki et al., 1974; Kieft and Ahmadjian, 1989; DeMott and Prenni, 2010; Atkinson et al., 2013; Hiranuma et al., 2013; Joly et al., 2013; Pummer et al., 2015; Fröhlich-Nowoisky et al., 2016; Kunert et al., 2019; Huang et al., 2021).

To further characterize the IN of the different aerosol samples, filtration and heat treatment experiments were performed with the aqueous extracts. Figure 8 shows that filtration through a $5 \mu \mathrm{m}$ and a $0.1 \mu \mathrm{m}$ filter reduced the ice nucleation activity in all samples, indicating that all samples contained IN larger than $5 \mu \mathrm{m}$, IN between $0.1 \mu \mathrm{m}$ and $5 \mu \mathrm{m}$, and IN smaller than $0.1 \mu \mathrm{m}$. For samples CY14, CY23, CY26, CY31, and CY48, however, the results show only a small fraction of IN between $0.1 \mu \mathrm{m}$ and $5 \mu \mathrm{m}$, while many IN were smaller than $0.1 \mu \mathrm{m}$. Of all samples, CY18 and CY19 show the lowest percentage of frozen droplets after $0.1 \mu \mathrm{m}$ filtration, and thus, the lowest numbers of IN smaller than $0.1 \mu \mathrm{m}$ in the observed temperature range.

Heat sensitivity can indicate biological IN, as heat can reduce ice nucleation activity of many bio-IN (Pouleur et al., 1992; Henderson-Begg et al., 2009; Morris et al., 2013; Fröhlich-Nowoisky et al., 2015; Pummer et al., 2015; Hara et al., 2016a; Kunert et al., 2019). Certain bio-IN, however, such as Lysinibacillus, a heat-resistant isolate of Xanthomonas, and various plant pollen, as well as inorganic particles are heat resistant to temperatures $>90^{\circ} \mathrm{C}$ (Pummer et al., 2012; Hill et al., 2014; Failor et al., 2017). Heat treatment at $98^{\circ} \mathrm{C}$ for $1 \mathrm{~h}$ reduced the ice nucleation activity of the individual samples to a different extent (Fig. 8). For example, the ice nucleation activity of samples CY20-CY32 was significantly reduced in the different size fractions after heat treatment (Fig. 8d-h), indicating the presence of heat-sensitive IN and thus presumably bio-IN of different sizes. Many fungal spores and bacterial aggregates are larger than $5 \mu \mathrm{m}$, whereas single bacterial cells or cell fragments can 
https://doi.org/10.5194/bg-2021-187

Preprint. Discussion started: 9 August 2021

(c) Author(s) 2021. CC BY 4.0 License.

(c) (i)

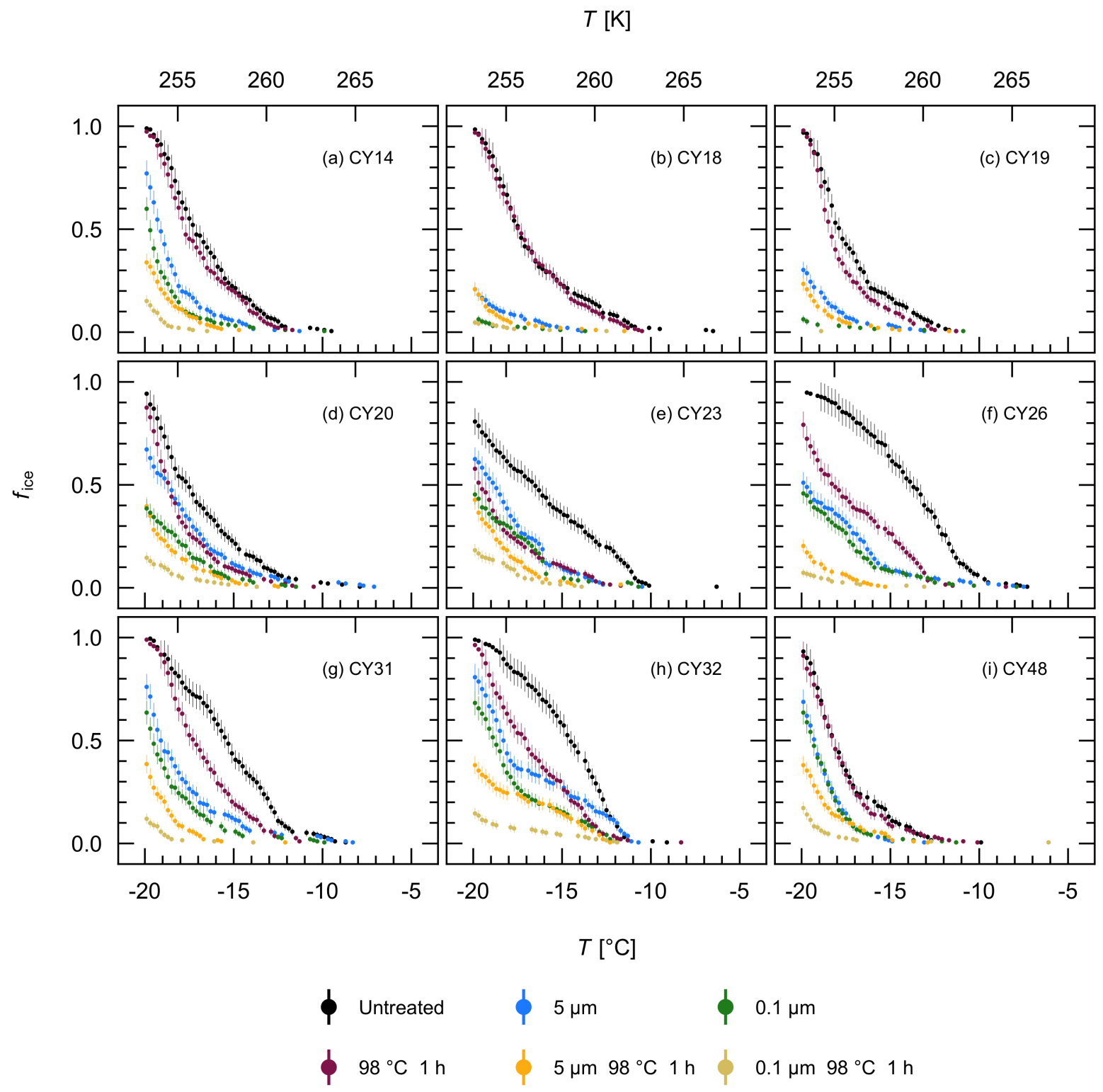

Figure 8. Effects of filtration and heat treatment on ice nucleation activity. Fraction of frozen droplets $\left(f_{\text {ice }}\right)$ vs. temperature $(T)$ for all aerosol samples (a-i). The color represents individual treatments; the error bars were calculated using the counting error and the Gaussian error propagation.

be smaller than $5 \mu \mathrm{m}$, and ice nucleating macromolecules are typically in the submicrometer range (Fröhlich-Nowoisky et al., 2016; Pummer et al., 2012, 2015; Šantl-Temkiv et al., 2015; Felgitsch et al., 2018). The samples CY23 and CY26, which were collected during and after the rain events, appear to have the largest fraction of heat-sensitive IN larger than $5 \mu \mathrm{m}$. In contrast, 
https://doi.org/10.5194/bg-2021-187

Preprint. Discussion started: 9 August 2021

(c) Author(s) 2021. CC BY 4.0 License.

\section{(c) ${ }_{\mathrm{BY}}$}

heat did only slightly affect samples CY18 and CY19 (Fig. 8b-c), indicating a significant fraction of heat-resistant IN in these samples, possibly due to particles from the dust events, which were registered during the collection of these samples (Fig. A1). For samples CY14 and CY48, the ice nucleation activity of $5 \mu \mathrm{m}$ and $0.1 \mu \mathrm{m}$ filtrates was reduced by heat, while the unfiltered extract was only slightly affected (Fig. 8a,i). The results suggest, that in these samples, many heat-resistant IN were larger than $5 \mu \mathrm{m}$, whereas many heat-sensitive IN were smaller than $0.1 \mu \mathrm{m}$, or, for CY14, also between $0.1 \mu \mathrm{m}$ and $5 \mu \mathrm{m}$.

\subsection{Possible sources of biological ice nuclei}

The results of the freezing experiments indicate the presence of bio-IN in different size ranges. These bio-IN may be present as living or dead cells, fungal hyphae and spores, pollen, cell fragments, detached macromolecules, or associated with plant particles or soil organic matter (Schnell and Vali, 1976; Pummer et al., 2012; Fröhlich-Nowoisky et al., 2015; Šantl-Temkiv et al., 2015; O'Sullivan et al., 2016; Hill et al., 2016; Conen and Yakutin, 2018). Note that not all of these IN contain DNA, as for example ice nucleating macromolecules or cell membrane fragments with attached IN proteins, and are thus not covered by DNA analysis. The largest fraction of bio-IN $>5 \mu \mathrm{m}$ were detected in CY23 and CY26. For these samples, the sequencing results show a higher proportion of reads assigned to fungi, in particular Agaricomycetes (Fig. 1,2), suggesting a possible contribution of these fungi to the increase of IN. Systematic surveys suggest that fungal ice nucleation activity, in particular at temperatures $>-15^{\circ} \mathrm{C}$, is restricted to a limited number of fungal species (Fröhlich-Nowoisky et al., 2015; Haga et al., 2013, 2014; Iannone et al., 2011; Jayaweera and Flanagan, 1982; Kieft and Ahmadjian, 1989; Kunert et al., 2019; Morris et al., 2013; Pouleur et al., 1992; Pummer et al., 2013, 2015). The class Agaricomycetes contains approximately 21000 fungal species (Hibbett et al., 2014), but only a handful has been tested for ice nucleation activity so far (Pummer et al., 2013; Haga et al., 2014). Further surveys of ice nucleation properties of Agaricomycetes and other fungi are necessary.

To identify possible bio-IN sources, the SSU and LSU data were analyzed for known IN fungi and bacteria that are active at temperatures $>-15^{\circ} \mathrm{C}$. In total, 4 fungal genera and 13 bacterial genera that contain IN-active species were detected, but all exhibited read proportions $<1 \%$ and species identification was partly not possible. Note that not all species and strains of the identified genera are IN-active, and, especially in bacteria, not all cells express the IN gene (Lindow et al., 1982; Kunert et al., 2019). Moreover, some recently isolated IN-active fungi and bacteria such as Cryptococcus sp. and Brevibacterium sp. are not identified to species level (Beall et al., 2021). Thus, the following microorganisms represent possible sources of IN but provide no proof to what extent they were $\mathrm{IN}$-active in the air.

Among the fungi were Cryptococcus sp., Fusarium sp., the soil-fungus Mortierella alpina, and five species of the plantpathogen rust fungi Puccinia (P. arachidis, P. hordei, P. horiana, P. striiformis, P. triticina). Spores of Puccinia striiformis (stripe rust or yellow rust) and P. triticinacan have initial freezing temperatures of $-7^{\circ} \mathrm{C}$ and $-9^{\circ} \mathrm{C}$, respectively (Morris et al., 2013). Although several other rust species are known as ice nucleators, for $P$. arachidis (peanut rust), $P$. hordei (barley leaf rust), and $P$. horiana (chrysanthemum white rust), ice nucleation activity has not yet been reported. In contrast to Puccinia spp., for which the spores are IN-active, the IN of M. alpina and Fusarium spp. are cell-free proteinous macromolecules and can trigger freezing at temperatures as high as $-5^{\circ} \mathrm{C}$ or $-1{ }^{\circ} \mathrm{C}$, respectively (Pouleur et al., 1992; Richard et al., 1996; Fröhlich-Nowoisky 
https://doi.org/10.5194/bg-2021-187

Preprint. Discussion started: 9 August 2021

(c) Author(s) 2021. CC BY 4.0 License.

(c) (i)

et al., 2015; Kunert et al., 2019). The macromolecules might be released into the surrounding environment and contribute to atmospheric IN.

Among the potential IN-active bacteria were the well-known genera and species Erwinia, Pantoea agglomerans, Pseudomonas, and Xanthomonas as well as the recently identified Brevibacterium, Idiomarina, Lysinibacillus, Planococcus maritimus, Psychrobacter (Maki et al., 1974; Govindarajan and Lindow, 1988; Hill et al., 2014; Failor et al., 2017; Beall et al., 2021). The genus Pseudomonas, which includes a range of IN-active species, was detected in all samples. Most of the reads ( $\sim 94 \%$ ) assigned to the genus Pseudomonas, however, could not be identified to species level. The remaining 58 reads were distributed over 12 species ( 1 to 14 reads per species), but did not include $P$. syringae a common bacterial ice nucleator. Analysis of the InterPro matches for IN-active proteins, however, revealed one InterPro match (IPR000258, bacterial ice-nucleation, octamer repeat) for in total 24 reads from six of the nine samples (1 to 12 reads per sample) indicating the presence of a bacterial IN-active species. Recently, ice nucleation activity was found in Halococcus morrhuae and Haloferax sulfurifontis; two species of Haloarchaea, which initiated the freezing of water droplets at temperatures as high as $-18{ }^{\circ} \mathrm{C}(\mathrm{Creamean}$ et al., 2021). In our data set, however, only one read from CY48 was assigned to the genus Halococcus, while Haloferax was not detected.

\section{Conclusions}

Our results show that rainfall in a rural dryland can lead to short-term changes of bioaerosol and IN composition. Particle washout and fungal spore discharge in response to humidity changes appear to play a major role for the observed composition changes, in particular for fungi and bacteria. The results of the freezing experiments suggest a rain-related enhancement of bio-IN $>5 \mu \mathrm{m}$ and $<0.1 \mu \mathrm{m}$. Microorganisms that are known to be IN-active, however, could only rarely been detected. This may reflect unknown sources of atmospheric bio-IN and the presence of cell fragments or cell-free IN macromolecules that do not contain DNA, as known for many IN-active fungi. Similar observations of increased bioaerosol, fungal spore, and IN concentrations in relation to rainfall have been reported for different ecosystems indicating a strong coupling of rainfall and particle emission (Huffman et al., 2013; Prenni et al., 2013; Schumacher et al., 2013; Tobo et al., 2013; Wright et al., 2014; Bigg et al., 2015; Heo et al., 2014; Gosselin et al., 2016; Rathnayake et al., 2017). The release of bioaerosols during and after rain may play an important role in the spread and reproduction of microorganisms and may contribute to the atmospheric transmission of pathogenic and allergenic particles. In view of the relevance of bioparticles as pathogens and allergens as well as nuclei for clouds and precipitation (bioprecipitation cycle) (Bigg et al., 2015; Morris et al., 2014, 2017) and potential future developments in the Anthropocene (Crutzen and Stoermer, 2000; Pöschl and Shiraiwa, 2015; Rodriguez-Caballero et al., 2018), further investigations are required to understand the sources, properties, and short-term dynamics of bioaerosols and bio-IN in various ecosystems. In particular, further investigations are necessary for the identification of the IN macromolecules and for the detection and quantification of these IN in soil, precipitation, and atmospheric samples. 
https://doi.org/10.5194/bg-2021-187

Preprint. Discussion started: 9 August 2021

(C) Author(s) 2021. CC BY 4.0 License.

(c) (1)

Data availability. The metagenomic data have been deposited at https://www.ebi.ac.uk/metagenomics/ under:

MGYA00166510 (CY14), MGYA00199054 (CY18), MGYA00166484 (CY19), MGYA00166504 (CY20), MGYA00166527 (CY23),

MGYA00166526 (CY26), MGYA00166493 (CY31), MGYA00199055 (CY32), MGYA00166518 (CY48). The IN data are available at Ed-

375 mond - the Open Access Data Repository of the Max Planck Society, under https://dx.doi.org/10.17617/3.6r. 
https://doi.org/10.5194/bg-2021-187

Preprint. Discussion started: 9 August 2021

(c) Author(s) 2021. CC BY 4.0 License.

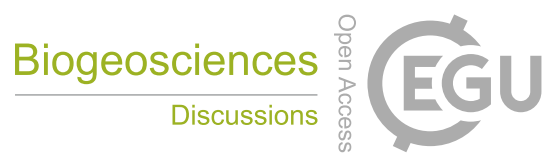

(c) (1)

Appendix A: Aerosol samples and meteorological conditions.

Table A1. Overview of air filter samples. Sample names, sampling periods, and sampled air volumes at standard conditions $\left(0{ }^{\circ} \mathrm{C}, 1013\right.$ $\mathrm{hPa})$.

\begin{tabular}{ccccccc}
\hline Sample & \multicolumn{2}{c}{ Start of Sampling } & \multicolumn{2}{c}{ End of Sampling } & Sampling Time & Sampled Air Volume \\
& Date & Time [LT] & Date & Time [LT] & [min] & [ $^{3}$ ] \\
\hline CY14 & 07 April 2016 & 09:41 & 08 April 2016 & $09: 41$ & 1440 & 1338 \\
CY18 & 09 April 2016 & 09:52 & 10 April 2016 & $09: 52$ & 1440 & 1330 \\
CY19 & 10 April 2016 & 09:54 & 11 April 2016 & $09: 52$ & 1440 & 1350 \\
CY20 & 11 April 2016 & 09:54 & 12 April 2016 & $09: 52$ & 1440 & 1358 \\
CY23 & 12 April 2016 & 10:02 & 13 April 2016 & $09: 56$ & 1429 & 1350 \\
CY26 & 13 April 2016 & 10:01 & 14 April 2016 & $10: 01$ & 1440 & 1350 \\
CY31 & 16 April 2016 & 10:07 & 17 April 2016 & $10: 07$ & 1440 & 1351 \\
CY32 & 17 April 2016 & 10:07 & 18 April 2016 & $10: 07$ & 1440 & 1344 \\
CY48 & 25 April 2016 & 10:01 & 26 April 2016 & $10: 01$ & 1440 & 1349 \\
\hline
\end{tabular}



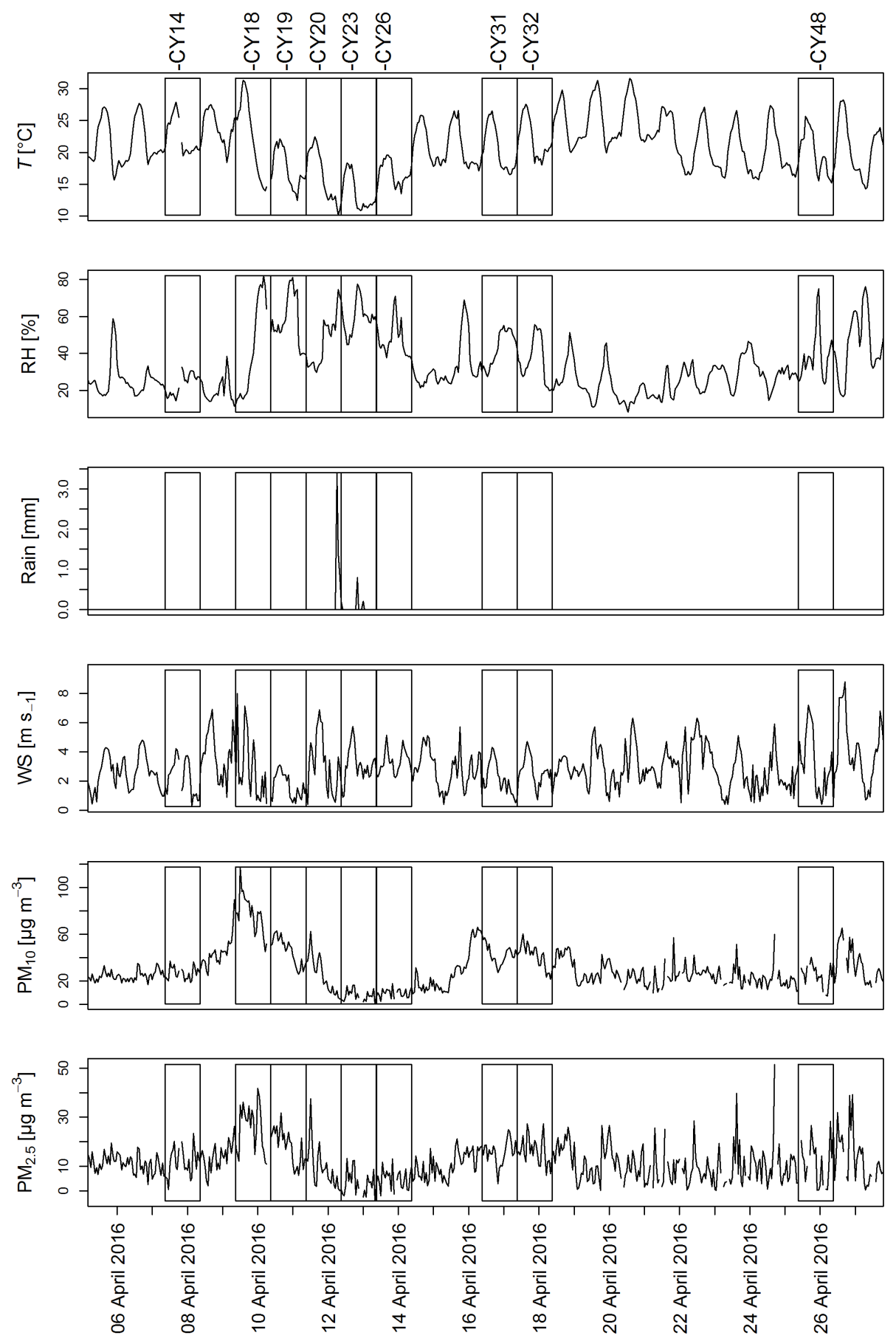

Figure A1. Meteorological conditions and aerosol mass concentrations. One-hour averages of temperature (T), relative humidity (RH), rain fall (Rain), wind speed (WS), and aerosol mass concentrations of $\mathrm{PM}_{10}$ and $\mathrm{PM}_{2.5}$ during the sampling campaign. 
https://doi.org/10.5194/bg-2021-187

Preprint. Discussion started: 9 August 2021

(c) Author(s) 2021. CC BY 4.0 License.

Appendix B: Freezing experiments with pure water and sampling blanks.

(a)

$T[\mathrm{~K}]$

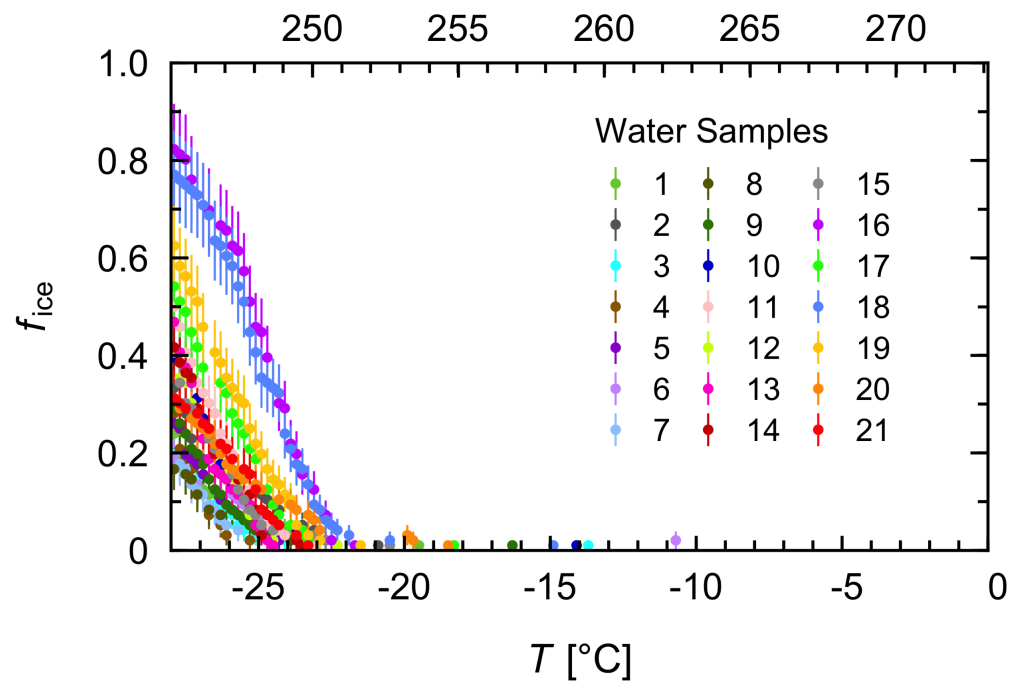

(b)

$T[\mathrm{~K}]$

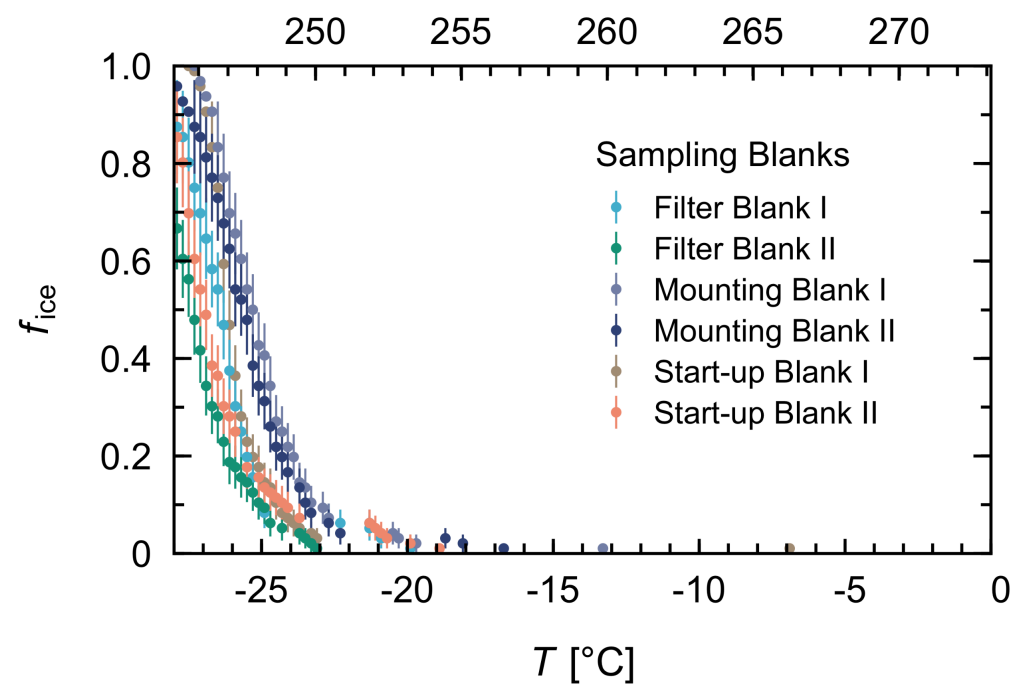

Figure B1. Negative controls of the freezing experiments. Fraction of frozen droplets $\left(f_{\text {ice }}\right)$ vs. temperature $(T)$ for all water samples (a) and different types of sampling blanks that served as negative controls (b). For each type of sampling blank, two filter pieces were measured. The error bars were calculated using the counting error and the Gaussian error propagation. 
https://doi.org/10.5194/bg-2021-187

Preprint. Discussion started: 9 August 2021

(c) Author(s) 2021. CC BY 4.0 License.

\section{Appendix C: InterPro matches and read counts for allergenic proteins.}

Table C1. Protein-encoding reads for allergens. Overview of InterPro matches and read counts for allergenic protein-encoding reads. IPR indicates the InterPro accession number.

\begin{tabular}{|c|c|c|c|c|c|c|c|c|c|c|c|}
\hline IPR & Allergens & Species/Family & CY14 & CY18 & CY19 & CY20 & CY23 & CY26 & CY31 & CY32 & CY48 \\
\hline \multicolumn{12}{|c|}{ Fungi } \\
\hline IPR032382 & Alt 1 & $\begin{array}{l}\text { Alternaria } \\
\text { alternata }\end{array}$ & 0 & 8 & 0 & 0 & 15 & 23 & 23 & 16 & 7 \\
\hline \multicolumn{12}{|c|}{ Viridiplantae } \\
\hline IPR005611 & Amb 5 & Ambrosia sp. & 4 & 9 & 0 & 0 & 3 & 4 & 3 & 0 & 1 \\
\hline IPR018082 & Amb & $\begin{array}{l}\text { Asteraceae, } \\
\text { Cupressaceae }\end{array}$ & 30 & 56 & 31 & 31 & 22 & 86 & 31 & 11 & 35 \\
\hline IPR024949 & Bet v1 type & $\begin{array}{l}\text { Betulaceae, } \\
\text { Apiaceae, } \\
\text { Rosaceae, } \\
\text { Asparagaceae, } \\
\text { Fabaceae, } \\
\text { Solanaceae }\end{array}$ & 0 & 9 & 4 & 9 & 8 & 63 & 7 & 7 & 20 \\
\hline IPR005795 & Lol p1 & Lolium perenne & 5 & 17 & 0 & 24 & 2 & 24 & 12 & 10 & 11 \\
\hline IPR005453 & Lol p2 & Lolium perenne & 0 & 1 & 0 & 0 & 0 & 0 & 1 & 0 & 0 \\
\hline IPR006040 & Ole e 1 & Olea europaea & 0 & 0 & 0 & 0 & 0 & 0 & 3 & 0 & 4 \\
\hline IPR035506 & $\begin{array}{l}\text { Pollen aller- } \\
\text { gen/Os }\end{array}$ & Oryza sativa & 1 & 4 & 1 & 2 & 3 & 2 & 9 & 0 & 17 \\
\hline IPR000528 & $\operatorname{Par} \mathrm{j} 1 / 2$ & $\begin{array}{l}\text { Parietaria } \\
\text { judaica }\end{array}$ & 11 & 2 & 5 & 0 & 14 & 20 & 154 & 0 & 18 \\
\hline IPR002411 & Amyl Inhib & Poaceae & 0 & 0 & 0 & 0 & 0 & 2 & 0 & 0 & 0 \\
\hline IPR002914 & $\begin{array}{l}\text { Lol p5, Pha } \\
\text { a5, Poa p9, Phl } \\
\text { p5b, Phl p6 }\end{array}$ & Poaceae & 0 & 3 & 0 & 0 & 0 & 4 & 0 & 0 & 8 \\
\hline IPR006106 & $\begin{array}{l}\text { Soft/Tryp Amyl } \\
\text { Inhib CS }\end{array}$ & Poaceae & 0 & 14 & 0 & 0 & 0 & 1 & 4 & 0 & 4 \\
\hline IPR006105 & $\begin{array}{l}\text { Tryp Amyl In- } \\
\text { hib CS }\end{array}$ & Poaceae & 0 & 15 & 0 & 0 & 1 & 0 & 2 & 0 & 0 \\
\hline \multicolumn{12}{|c|}{ Metazoa } \\
\hline IPR032487 & ABA 1, DvA1 & $\begin{array}{l}\text { Ascarididae, } \\
\text { Dictyocaulidae }\end{array}$ & 4 & 0 & 2 & 0 & 0 & 0 & 0 & 0 & 0 \\
\hline
\end{tabular}


https://doi.org/10.5194/bg-2021-187

Preprint. Discussion started: 9 August 2021

(c) Author(s) 2021. CC BY 4.0 License.

\begin{tabular}{|c|c|c|c|c|c|c|c|c|c|c|c|}
\hline \multicolumn{12}{|c|}{ continued from previous page } \\
\hline IPR & Allergens & Species/Family & CY14 & CY18 & CY19 & CY20 & CY23 & CY26 & CY31 & CY32 & CY48 \\
\hline IPR002116 & Api m3 & Apis mellifera & 0 & 0 & 19 & 2 & 0 & 0 & 0 & 21 & 1 \\
\hline IPR002450 & Bos d2, Can f2 & $\begin{array}{l}\text { Bovidae, } \\
\text { Canidae }\end{array}$ & 0 & 0 & 0 & 0 & 0 & 0 & 1 & 0 & 0 \\
\hline IPR020234 & Der f7 & $\begin{array}{l}\text { Dermatophago- } \\
\text { ides farinae }\end{array}$ & 10 & 1 & 1 & 0 & 2 & 1 & 0 & 0 & 12 \\
\hline IPR020306 & $\begin{array}{l}\text { Der p5, Blo t5, } \\
\text { Blo t } 21\end{array}$ & $\begin{array}{l}\text { Dermatophago- } \\
\text { ides pteronyssi- } \\
\text { nus, Blomia } \\
\text { tropicalis }\end{array}$ & 0 & 17 & 0 & 3 & 0 & 6 & 0 & 8 & 6 \\
\hline IPR006178 & Fel d1 (chain 1) & Felis silvestris & 0 & 0 & 0 & 0 & 0 & 0 & 1 & 0 & 0 \\
\hline IPR015332 & Fel d1 (chain 2) & Felis silvestris & 0 & 0 & 0 & 0 & 0 & 1 & 0 & 0 & 0 \\
\hline IPR010629 & NSP & Pieris rapae & 0 & 2 & 0 & 6 & 0 & 0 & 2 & 0 & 0 \\
\hline IPR018244 & $\begin{array}{l}\text { Ves m5 /Ves v5 } \\
(\mathrm{CS})\end{array}$ & Vespidae & 34 & 149 & 138 & 72 & 221 & 188 & 387 & 80 & 193 \\
\hline IPR001283 & Ves m5 /Ves v5 & Vespidae & 48 & 143 & 59 & 48 & 159 & 175 & 377 & 60 & 192 \\
\hline IPR002413 & Ves 5 type & $\begin{array}{l}\text { Vespidae, } \\
\text { Formicidae }\end{array}$ & 5 & 21 & 9 & 2 & 27 & 48 & 91 & 2 & 44 \\
\hline
\end{tabular}


https://doi.org/10.5194/bg-2021-187

Preprint. Discussion started: 9 August 2021

(C) Author(s) 2021. CC BY 4.0 License.

(c) (1)

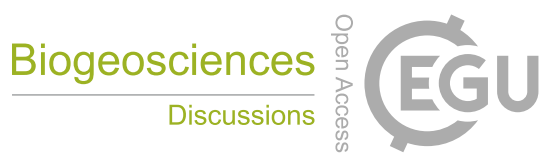

Author contributions. JF-N, UP, and BW designed the study. PY performed the sample collection and DNA extraction. KT performed the freezing experiments. BS-P, DP, JW, JF-N, KT, and PY analyzed the taxonomic data. BS-P and JF-N analyzed the InterPro matches. KT and

385 ATB analyzed the IN data. All authors discussed the results. JF-N wrote the manuscript with contributions from all co-authors.

Competing interests. The authors declare that they have no conflict of interest.

Acknowledgements. We thank the entire INUIT-BACCHUS-ACTRIS campaign team for their cooperation and support, the Cyprus Department of Labour of Inspection for the provision of meteorological and PM data, N. Kropf, N. Lang-Yona, and S. Lelieveld for technical assistance, N. Bothen, J. A. Huffman, and M. L. Pöhlker for helpful discussion, the Max Planck Society (MPG), the Horizon 2020 AC-

TRIS project (grant agreement No 654109) and its provision of transnational access funds, and the Deutsche Forschungsgemeinschaft (DFG, FR3641/1-2, FOR 1525 INUIT) for financial support. 
https://doi.org/10.5194/bg-2021-187

Preprint. Discussion started: 9 August 2021

(c) Author(s) 2021. CC BY 4.0 License.

(c) (i)

\section{References}

Almeida, A., Mitchell, A. L., Boland, M., Forster, S. C., Gloor, G. B., Tarkowska, A., Lawley, T. D., and Finn, R. D.: A new genomic blueprint of the human gut microbiota, Nature, 568, 499-504, https://doi.org/10.1038/s41586-019-0965-1, 2019.

Andreae, M. O. and Rosenfeld, D.: Aerosol-cloud-precipitation interactions. Part 1. The nature and sources of cloud-active aerosols, EarthScience Rev., 89, 13-41, https://doi.org/10.1016/j.earscirev.2008.03.001, 2008.

Archer, S. D. J., Lee, K. C., Caruso, T., King-Miaow, K., Harvey, M., Huang, D., Wainwright, B. J., and Pointing, S. B.: Air mass source determines airborne microbial diversity at the ocean-atmosphere interface of the Great Barrier Reef marine ecosystem, ISME J., 14, 871-876, https://doi.org/10.1038/s41396-019-0555-0, 2020.

Atkinson, J. D., Murray, B. J., Woodhouse, M. T., Whale, T. F., Baustian, K. J., Carslaw, K. S., Dobbie, S., O’Sullivan, D., and Malkin, T. L.: The importance of feldspar for ice nucleation by mineral dust in mixed-phase clouds, Nature, 498, 355-358, https://doi.org/10.1038/nature12278, 2013.

Beall, C. M., Michaud, J. M., Fish, M. A., Dinasquet, J., Cornwell, G. C., Stokes, M. D., Burkart, M. D., Hill, T. C., DeMott, P. J., and Prather, K. A.: Cultivable halotolerant ice-nucleating bacteria and fungi in coastal precipitation, Atmos. Chem. Phys., 21, 9031-9045, https://doi.org/10.5194/acp-21-9031-2021, 2021.

Bigg, E. K., Soubeyrand, S., and Morris, C. E.: Persistent after-effects of heavy rain on concentrations of ice nuclei and rainfall suggest a biological cause, Atmos. Chem. Phys., 15, 2313-2326, https://doi.org/10.5194/acp-15-2313-2015, 2015.

Bik, H. M.: Microbial Metazoa Are Microbes Too, mSystems, 4, 1-4, https://doi.org/10.1128/msystems.00109-19, 2019.

Bowers, R. M., McLetchie, S., Knight, R., and Fierer, N.: Spatial variability in airborne bacterial communities across land-use types and their relationship to the bacterial communities of potential source environments., ISME J., 5, 601-612, https://doi.org/10.1038/ismej.2010.167, 2011.

Bowers, R. M., McCubbin, I. B., Hallar, A. G., and Fierer, N.: Seasonal variability in airborne bacterial communities at a high-elevation site, Atmos. Environ., 50, 41-49, https://doi.org/10.1016/j.atmosenv.2012.01.005, 2012.

Bowers, R. M., Clements, N., Emerson, J. B., Wiedinmyer, C., Hannigan, M. P., and Fierer, N.: Seasonal variability in bacterial and fungal diversity of the near-surface atmosphere, Environ. Sci. Technol., 47, 12 097-12 106, https://doi.org/10.1021/es402970s, 2013.

Brown, J. K. M. and Hovmøller, M. S.: Aerial dispersal of pathogens on the global and continental scales and its impact on plant disease, Science, 297, 537-541, https://doi.org/10.1126/science.1072678, 2002.

Burrows, S. M., Hoose, C., Pöschl, U., and Lawrence, M. G.: Ice nuclei in marine air: Biogenic particles or dust?, Atmos. Chem. Phys., 13, 245-267, https://doi.org/10.5194/acp-13-245-2013, 2013.

Cao, C., Jiang, W., Wang, B., Fang, J., Lang, J., Tian, G., Jiang, J., and Zhu, T. F.: Inhalable Microorganisms in Beijing ' s PM 2.5 and PM 10 Pollutants during a Severe Smog Event, Enviromental Sci. Technol., 48, 1499-1507, https://doi.org/10.1021/es4048472, 2014.

Carroll, J. J. and Viglierchio, D. R.: On the transport of nematodes by the wind., J. Nematol., 13, 476-83, http://www.ncbi.nlm.nih.gov/ pubmed/19300792http://www.pubmedcentral.nih.gov/articlerender.fcgi?artid=PMC2618129, 1981.

Ciprandi, G., Puccinelli, P., Incorvaia, C., and Masieri, S.: Parietaria allergy: An intriguing challenge for the allergist, Med., 54, 1-10, https://doi.org/10.3390/MEDICINA54060106, 2018.

Colombo, P., Bonura, A., Costa, M. A., Izzo, V., Passantino, R., Locorotondo, G., Amoroso, S., and Geraci, D.: The Allergens of Parietaria, Int. Arch. Allergy Immunol., 130, 173-179, https://doi.org/10.1159/000069520, 2003. 
https://doi.org/10.5194/bg-2021-187

Preprint. Discussion started: 9 August 2021

(c) Author(s) 2021. CC BY 4.0 License.

(c) (i)

Coluzza, I., Creamean, J., Rossi, J. M., Wex, H., Alpert, A. P., Bianco, V., Boose, Y., Dellago, C., Felgitsch, L., Fröhlich-Nowoisky, J., Herrmann, H., Jungblut, S., Kanji, A. Z., Menzl, G., Moffett, B., Moritz, C., Mutzel, A., Pöschl, U., Schauperl, M., Scheel, J., Stopelli, E., Stratmann, F., Grothe, H., and Schmale, G. D.: Perspectives on the Future of Ice Nucleation Research: Research Needs and Unanswered Questions Identified from Two International Workshops, https://doi.org/10.3390/atmos8080138, 2017.

Conen, F. and Yakutin, M. V.: Soils rich in biological ice-nucleating particles abound in ice-nucleating macromolecules likely produced by fungi, Biogeosciences, 15, 4381-4385, https://doi.org/10.5194/bg-15-4381-2018, 2018.

Crandall, S. G. and Gilbert, G. S.: Meteorological factors associated with abundance of airborne fungal spores over natural vegetation, Atmos.

Environ., 162, 87-99, https://doi.org/10.1016/j.atmosenv.2017.05.018, 2017.

Creamean, J. M., Ceniceros, J. E., Newman, L., Pace, A. D., Hill, T. C. J., DeMott, P. J., and Rhodes, M. E.: Evaluating the potential for Haloarchaea to serve as ice nucleating particles, Biogeosciences, 18, 3751-3762, https://doi.org/10.5194/bg-18-3751-2021, 2021.

Crutzen, P. J. and Stoermer, E. F.: The "Anthropocene", Glob. Chang. Newsl., 41, 17-18, 2000.

D’Amato, G., Cecchi, L., Bonini, S., Nunes, C., Annesi-Maesano, I., Behrendt, H., Liccardi, G., Popov, T., and Van Cauwenberge, P.: Allergenic pollen and pollen allergy in Europe, Allergy Eur. J. Allergy Clin. Immunol., 62, 976-990, https://doi.org/10.1111/j.13989995.2007.01393.x, 2007.

DeMott, P. J. and Prenni, A. J.: New Directions: Need for defining the numbers and sources of biological aerosols acting as ice nuclei, Atmos. Environ., 44, 1944-1945, https://doi.org/10.1016/j.atmosenv.2010.02.032, 2010.

Després, V. R., Alex Huffman, J., Burrows, S. M., Hoose, C., Safatov, A. S., Buryak, G., Fröhlich-Nowoisky, J., Elbert, W., Andreae, M. O., Pöschl, U., Jaenicke, R., Huffman, J. A., Burrows, S. M., Hoose, C., Safatov, A. S., Buryak, G., Fröhlich-Nowoisky, J., Elbert, W., Andreae, M. O., Pöschl, U., and Jaenicke, R.: Primary biological aerosol particles in the atmosphere: a review, Tellus B, 64, https://doi.org/10.3402/tellusb.v64i0.15598, 2012

Edwards, R. A. and Rohwer, F.: Viral metagenomics, Nat. Rev. Microbiol., 3, 504-510, https://doi.org/10.1038/nrmicro1163, 2005.

Elbert, W., Taylor, P. E., Andreae, M. O., and Pöschl, U.: Contribution of fungi to primary biogenic aerosols in the atmosphere: wet and dry discharged spores, carbohydrates, and inorganic ions, Atmos. Chem. Phys., 7, 4569-4588, https://doi.org/10.5194/acp-7-4569-2007, 2007.

Failor, K. C., Schmale, D. G., Vinatzer, B. A., and Monteil, C. L.: Ice nucleation active bacteria in precipitation are genetically diverse and nucleate ice by employing different mechanisms, ISME J., 11, 2740-2753, https://doi.org/10.1038/ismej.2017.124, 2017.

Fall, P. L.: Modern vegetation, pollen and climate relationships on the Mediterranean island of Cyprus, Rev. Palaeobot. Palynol., 185, 79-92, https://doi.org/10.1016/j.revpalbo.2012.08.002, 2012.

Felgitsch, L., Baloh, P., Burkart, J., Mayr, M., Momken, M. E., Seifried, T. M., Winkler, P., Schmale, D. G., and Grothe, H.: Birch leaves and branches as a source of ice-nucleating macromolecules, Atmos. Chem. Phys., 18, 16 063-16 079, https://doi.org/10.5194/acp-18-16063$2018,2018$.

Fendrihan, S., Legat, A., Pfaffenhuemer, M., Gruber, C., Weidler, G., Gerbl, F., and Stan-Lotter, H.: Extremely halophilic archaea and the issue of long-term microbial survival, Life Extrem. Environ., 9781402062, 125-140, https://doi.org/10.1007/978-1-4020-6285-8_8, 2007.

Franzetti, A., Gandolfi, I., Gaspari, E., Ambrosini, R., and Bestetti, G.: Seasonal variability of bacteria in fine and coarse urban air particulate matter, Appl. Microbiol. Biotechnol., 90, 745-753, https://doi.org/10.1007/s00253-010-3048-7, 2011.

Fröhlich-Nowoisky, J., Ruzene Nespoli, C., Pickersgill, D. A., Galand, P. E., Müller-Germann, I., Nunes, T., Gomes Cardoso, J., Almeida, S. M., Pio, C., Andreae, M. O., Conrad, R., Pöschl, U., Després, V. R., Pickersgil, D. A., Galand, P. E., Müller-Germann, I., Nunes, T., Gomes Cardoso, J., Almeida, S. M., Pio, C., Andreae, M. O., Conrad, R., Pöschl, U., Després, V. R., Pickersgill, D. A., Galand, P. E., 
https://doi.org/10.5194/bg-2021-187

Preprint. Discussion started: 9 August 2021

(c) Author(s) 2021. CC BY 4.0 License.

(c) (i)

Müller-Germann, I., Nunes, T., Gomes Cardoso, J., Almeida, S. M., Pio, C., Andreae, M. O., Conrad, R., Pöschl, U., Després, V. R., Müller-German, I., Vogel, B., Nunes, T., Gomes Cardoso, J., Marta Almeida, S., Pio, C., Andreae, M. O., Conrad, R., Pöschl, U., and Després, V. R.: Diversity and seasonal dynamics of airborne archaea, Biogeosciences, 11, 6067-6079, https://doi.org/10.5194/bg-11-60672014, 2014.

Fröhlich-Nowoisky, J., Hill, T. C. J., Pummer, B. G., Yordanova, P., Franc, G. D., and Pöschl, U.: Ice nucleation activity in the widespread soil fungus Mortierella alpina, Biogeosciences, 12, 1057-1071, https://doi.org/10.5194/bg-12-1057-2015, 2015.

Fröhlich-Nowoisky, J., Kampf, C. J., Weber, B., Huffman, J. A., Pöhlker, C., Andreae, M. O., Lang-Yona, N., Burrows, S. M., Gunthe, S. S., Elbert, W., Su, H., Hoor, P., Thines, E., Hoffmann, T., Després, V. R., and Pöschl, U.: Bioaerosols in the Earth system: Climate, health, and ecosystem interactions, Atmos. Res., 182, 346-376, https://doi.org/10.1016/j.atmosres.2016.07.018, 2016.

Gandolfi, I., Bertolini, V., Ambrosini, R., Bestetti, G., and Franzetti, A.: Unravelling the bacterial diversity in the atmosphere, Appl. Microbiol. Biotechnol., 97, 4727-4736, https://doi.org/10.1007/s00253-013-4901-2, 2013.

Gilet, T. and Bourouiba, L.: Rain-induced ejection of pathogens from leaves: Revisiting the hypothesis of splash-on-film using high-speed visualization, Integr. Comp. Biol., 54, 974-984, https://doi.org/10.1093/icb/icu116, 2014.

Gong, X., Wex, H., Müller, T., Wiedensohler, A., Höhler, K., Kandler, K., Ma, N., Dietel, B., Schiebel, T., Möhler, O., and Stratmann, F.: Characterization of aerosol properties at Cyprus, focusing on cloud condensation nuclei and ice-nucleating particles, Atmos. Chem. Phys., 19, 10 883-10 900, https://doi.org/10.5194/acp-19-10883-2019, 2019.

Gosselin, M. I., Rathnayake, C. C. M., Crawford, I., Pöhlker, C., Fröhlich-Nowoisky, J., Schmer, B., Després, V. V. R., Engling, G., Gallagher, M., Stone, E., Pöschl, U., Huffman, J. A., Ila Gosselin, M., Rathnayake, C. C. M., Crawford, I., Pöhlker, C., Fröhlich-Nowoisky, J., Schmer, B., Després, V. V. R., Engling, G., Gallagher, M., Stone, E., Pöschl, U., and Alex Huffman, J.: Fluorescent bioaerosol particle, molecular tracer, and fungal spore concentrations during dry and rainy periods in a semi-arid forest, Atmos. Chem. Phys., 16, 15 165-15 184, https://doi.org/10.5194/acp-16-15165-2016, 2016.

Govindarajan, A. G. and Lindow, S. E.: Size of bacterial ice-nucleation sites measured in situ by radiation inactivation analysis, Proc. Natl. Acad. Sci., 85, 1334-1338, https://doi.org/10.1073/pnas.85.5.1334, 1988.

Grant, W. D. and Ross, H. N.: The ecology and taxonomy of halobacteria, FEMS Microbiol. Lett., 39, 9-15, https://doi.org/10.1016/03781097(86)90054-6, 1986

Gregory, P. H., Guthrie, E. J., and Bunce, M. E.: Experiments on splash dispersal of fungus spores., J. Gen. Microbiol., 20, 328-354, https://doi.org/10.1099/00221287-20-2-328, 1959.

Gucel, S., Guvensen, A., Ozturk, M., and Celik, A.: Analysis of airborne pollen fall in Nicosia (Cyprus), Environ. Monit. Assess., 185, 157-169, https://doi.org/10.1007/s10661-012-2540-1, 2013.

Haga, D., Burrows, S., Iannone, R., Wheeler, M., Mason, R., Chen, J., Polishchuk, E., Pöschl, U., and Bertram, A.: Ice nucleation by fungal spores from the classes Agaricomycetes, Ustilaginomycetes, and Eurotiomycetes, and the effect on the atmospheric transport of these spores, Atmos. Chem. Phys., 14, 8611-8630, https://doi.org/doi:10.5194/acp-14-8611-2014, 2014.

Haga, D. I., Iannone, R., Wheeler, M. J., Mason, R., Polishchuk, E. A., Fetch, T., van der Kamp, B. J., McKendry, I. G., and Bertram, A. K.: Ice nucleation properties of rust and bunt fungal spores and their transport to high altitudes, where they can cause heterogeneous freezing, J. Geophys. Res. Atmos., 118, 7260-7272, https://doi.org/10.1002/jgrd.50556, 2013.

Hara, K., Maki, T., Kakikawa, M., Kobayashi, F., and Matsuki, A.: Effects of different temperature treatments on biological ice nuclei in snow samples, Atmos. Environ., 140, 415-419, https://doi.org/10.1016/j.atmosenv.2016.06.011, 2016a. 
https://doi.org/10.5194/bg-2021-187

Preprint. Discussion started: 9 August 2021

(c) Author(s) 2021. CC BY 4.0 License.

\section{(c) (i)}

Hara, K., Maki, T., Kobayashi, F., Kakikawa, M., Wada, M., and Matsuki, A.: Variations of ice nuclei concentration induced by rain and snowfall within a local forested site in Japan, Atmos. Environ., 127, 1-5, https://doi.org/10.1016/j.atmosenv.2015.12.009, 2016b.

Hassett, M. O., Fischer, M. W. F., and Money, N. P.: Mushrooms as rainmakers: How spores act as nuclei for raindrops, PLoS One, 10, e0140 407, https://doi.org/10.1371/journal.pone.0140407, 2015.

Henderson-Begg, S. K., Hill, T., Thyrhaug, R., Khan, M., and Moffett, B. F.: Terrestrial and airborne non-bacterial ice nuclei, Atmos. Sci. Lett., 10, 215-219, https://doi.org/10.1002/asl.241, 2009.

Heo, K. J., Kim, H. B., and Lee, B. U.: Concentration of environmental fungal and bacterial bioaerosols during the monsoon season, J. Aerosol Sci., 77, 31-37, https://doi.org/10.1016/j.jaerosci.2014.07.001, 2014.

Herridge, R., Samarth, R., Brownfield, L., and Macknight, R.: Identification and Characterization of Perennial Ryegrass (Lolium perenne) Vernalization Genes, Front. Plant Sci., 12, 1-12, https://doi.org/10.3389/fpls.2021.640324, 2021.

Hibbett, D. S., Bauer, R., Binder, M., Giachini, A. J., Hosaka, K., Justo, A., Larsson, E., Larsson, K. H., Lawrey, J. D., Miettinen, O., Nagy, L. G., Nilsson, R. H., Weiss, M., and Thorn, R. G.: Agaricomycetes, chap. 14, pp. 373-429, Springer Berlin Heidelberg, Berlin, Heidelberg, https://doi.org/10.1007/978-3-642-55318-9_14, 2014.

Hill, T. C. J., Moffett, B. F., DeMott, P. J., Georgakopoulos, D. G., Stump, W. L., and Franc, G. D.: Measurement of ice nucleation-active bacteria on plants and in precipitation by quantitative PCR, Appl. Environ. Microbiol., 80, 1256-1267, https://doi.org/10.1128/AEM.02967$13,2014$.

Hill, T. C. J., DeMott, P. J., Tobo, Y., Fröhlich-Nowoisky, J., Moffett, B. F., Franc, G. D., and Kreidenweis, S. M.: Sources of organic ice nucleating particles in soils, Atmos. Chem. Phys., 16, 7195-7211, https://doi.org/10.5194/acp-16-7195-2016, 2016.

Hiranuma, N., Möhler, O., Bingemer, H., Bundke, U., Cziczo, D. J., Danielczok, A., Ebert, M., Garimella, S., Hoffmann, N., Höhler, K., Kanji, Z. A., Kiselev, A., Raddatz, M., and Stetzer, O.: Immersion freezing of clay minerals and bacterial ice nuclei, AIP Conf. Proc., 1527, 914-917, https://doi.org/10.1063/1.4803420, 2013.

Hirst, J.: Changes in atmospheric spore content: Diurnal periodicity and the effects of weather, Trans. Br. Mycol. Soc., 36, 375-393, https://doi.org/10.1016/S0007-1536(53)80034-3, 1953

Hirst, J. M. and Stedman, O. J.: Dry Liberation of Fungus Spores By Raindrops., J. Gen. Microbiol., 33, 335-344, https://doi.org/10.1099/00221287-33-2-335, 1963.

Hoose, C. and Möhler, O.: Heterogeneous ice nucleation on atmospheric aerosols: a review of results from laboratory experiments, Atmos. Chem. Phys., 12, 9817-9854, https://doi.org/10.5194/acp-12-9817-2012, 2012.

Huang, S., Hu, W., Chen, J., Wu, Z., Zhang, D., and Fu, P.: Overview of biological ice nucleating particles in the atmosphere, Environ. Int., 146, 106 197, https://doi.org/10.1016/j.envint.2020.106197, 2021.

Huffman, J. A., Prenni, A. J., Demott, P. J., Pöhlker, C., Mason, R. H., Robinson, N. H., Fröhlich-Nowoisky, J., Tobo, Y., Després, V. R., Garcia, E., Gochis, D. J., Harris, E., Müller-Germann, I., Ruzene, C., Schmer, B., Sinha, B., Day, D. A., Andreae, M. O., Jimenez, J. L., Gallagher, M., Kreidenweis, S. M., Bertram, A. K., and Pöschl, U.: High concentrations of biological aerosol particles and ice nuclei during and after rain, Atmos. Chem. Phys., 13, 6151-6164, https://doi.org/10.5194/acp-13-6151-2013, 2013.

Iannone, R., Chernoff, D. I., Pringle, A., Martin, S. T., and Bertram, a. K.: The ice nucleation ability of one of the most abundant types of fungal spores found in the atmosphere, Atmos. Chem. Phys., 11, 1191-1201, https://doi.org/10.5194/acp-11-1191-2011, 2011.

Jang, G. I., Hwang, C. Y., and Cho, B. C.: Effects of heavy rainfall on the composition of airborne bacterial communities, Front. Environ. Sci. Eng., 12, 1-10 doi.org/10.1007/s11 783-018-1008-0, 2018. 
https://doi.org/10.5194/bg-2021-187

Preprint. Discussion started: 9 August 2021

(c) Author(s) 2021. CC BY 4.0 License.

(c) (i)

Jayaweera, K. and Flanagan, P.: Investigations on biogenic ice nuclei in the Arctic atmosphere, Geophys. Res. Lett., 9, 94-97, https://doi.org/10.1029/GL009i001p00094, 1982.

Jeon, E. M., Kim, H. J., Jung, K., Kim, J. H., Kim, M. Y., Kim, Y. P., and Ka, J. O.: Impact of Asian dust events on airborne bacterial community assessed by molecular analyses, Atmos. Environ., 45, 4313-4321, https://doi.org/10.1016/j.atmosenv.2010.11.054, 2011.

Joly, M., Attard, E., Sancelme, M., Deguillaume, L., Guilbaud, C., Morris, C. E., Amato, P., and Delort, A.-M.: Ice nucleation activity of bacteria isolated from cloud water, Atmos. Environ., 70, 392-400, https://doi.org/10.1016/j.atmosenv.2013.01.027, 2013.

Jones, A. M. and Harrison, R. M.: The effects of meteorological factors on atmospheric bioaerosol concentrations - A review, Sci. Total Environ., 326, 151-180, https://doi.org/10.1016/j.scitotenv.2003.11.021, 2004.

Joung, Y. S., Ge, Z., and Buie, C. R.: Bioaerosol generation by raindrops on soil, Nat. Commun., 8, 1-10, https://doi.org/10.1038/ncomms14668, 2017.

550 Kauserud, H., Lie, M., Stensrud, Ø., and Ohlson, M.: Molecular characterization of airborne fungal spores in boreal forests of contrasting human disturbance, Mycologia, 97, 1215-1224, https://doi.org/10.1080/15572536.2006.11832731, 2005.

Kaygusuz, O. and Faruk Çolak, Ö.: New records of Helotiales in Turkey, ScienceAsia, 43, 217, https://doi.org/10.2306/scienceasia15131874.2017.43.217, 2017.

Kho, Z. Y. and Lal, S. K.: The human gut microbiome - A potential controller of wellness and disease, Front. Microbiol., 9, 1-23, https://doi.org/10.3389/fmicb.2018.01835, 2018.

Kieft, T. L. and Ahmadjian, V.: Biological Ice Nucleation Activity in Lichen Mycobionts and Photobionts, Lichenol., 21, 355-362, https://doi.org/10.1017/S0024282989000599, 1989.

Kim, S., Park, H., Gruszewski, H. A., Schmale, D. G., and Jung, S.: Vortex-induced dispersal of a plant pathogen by raindrop impact, Proc. Natl. Acad. Sci., p. 201820318, https://doi.org/10.1073/pnas.1820318116, 2019.

560 Kluska, K., Piotrowicz, K., and Kasprzyk, I.: The impact of rainfall on the diurnal patterns of atmospheric pollen concentrations, Agric. For. Meteorol., 291, 108 042, https://doi.org/10.1016/j.agrformet.2020.108042, 2020.

Kunert, A. T., Lamneck, M., Helleis, F., Pöschl, U., Pöhlker, M. L., and Fröhlich-Nowoisky, J.: Twin-plate Ice Nucleation Assay (TINA) with infrared detection for high-throughput droplet freezing experiments with biological ice nuclei in laboratory and field samples, Atmos. Meas. Tech., 11, 6327-6337, https://doi.org/10.5194/amt-11-6327-2018, 2018.

Kunert, A. T., Pöhlker, M. L., Tang, K., Krevert, C. S., Wieder, C., Speth, K. R., Hanson, L. E., Morris, C. E., Schmale III, D. G., Pöschl, U., and Fröhlich-Nowoisky, J.: Macromolecular fungal ice nuclei in Fusarium: effects of physical and chemical processing, Biogeosciences, 16, 4647-4659, https://doi.org/10.5194/bg-16-4647-2019, 2019.

Lacey, J.: Spore dispersal - Its role in ecology and disease: The British contribution to fungal aerobiology, Mycol. Res., 100, 641-660, https://doi.org/10.1016/S0953-7562(96)80194-8, 1996.

570 Lang-Yona, N., Pickersgill, D. A., Maurus, I., Teschner, D., Wehking, J., Thines, E., Poschl, U., Després, V. R., and Frohlich-Nowoisky, J.: Species Richness, rRNA Gene Abundance, and Seasonal Dynamics of Airborne Plant-Pathogenic Oomycetes, Front. Microbiol., 9, 1-11, https://doi.org/10.3389/fmicb.2018.02673, 2018.

Lindow, S. E., Hirano, S. S., Barchet, W. R., Arny, D. C., and Upper, C. D.: Relationship between Ice Nucleation Frequency of Bacteria and Frost Injury, Plant Physiol., 70, 1090-1093, https://doi.org/10.1104/pp.70.4.1090, 1982.

575 Liu, Y. and Whitman, W. B.: Metabolic, phylogenetic, and ecological diversity of the methanogenic archaea, Ann. N. Y. Acad. Sci., 1125, 171-189, https://doi.org/10.1196/annals.1419.019, 2008. 
https://doi.org/10.5194/bg-2021-187

Preprint. Discussion started: 9 August 2021

(c) Author(s) 2021. CC BY 4.0 License.

\section{(c) (i)}

Löbs, N., Barbosa, C. G. G., Brill, S., Walter, D., Ditas, F., de Oliveira Sá, M., de Araújo, A. C., de Oliveira, L. R., Godoi, R. H. M., Wolff, S., Piepenbring, M., Kesselmeier, J., Artaxo, P., Andreae, M. O., Pöschl, U., Pöhlker, C., and Weber, B.: Aerosol measurement methods to quantify spore emissions from fungi and cryptogamic covers in the Amazon, Atmos. Meas. Tech., 13, 153-164, https://doi.org/doi: 10.5194/amt-13-153-2020, 2020.

Madden, L. V.: Effects of rain on splash dispersal of fungal pathogens, Can. J. Plant Pathol., 19, 225-230, https://doi.org/10.1080/07060669709500557, 1997

Maki, L. R., Galyan, E. L., Chang-Chien, M. M., and Caldwell, D. R.: Ice nucleation induced by Pseudomonas syringae., Appl. Microbiol., 28, 456-459, https://doi.org/10.1111/1462-2920.12668, 1974.

Matias Rodrigues, J. F., Schmidt, T. S., Tackmann, J., and Von Mering, C.: MAPseq: Highly efficient k-mer search with confidence estimates, for rRNA sequence analysis, Bioinformatics, 33, 3808-3810, https://doi.org/10.1093/bioinformatics/btx517, 2017.

McMurdie, P. J. and Paulson, J.: Biomformat: An interface package for the BIOM file format, 2019.

Mescioglu, E., Rahav, E., Belkin, N., Xian, P., Eizenga, J., Vichik, A., Herut, B., and Paytan, A.: Aerosol Microbiome over the Mediterranean Sea Diversity and Abundance, Atmosphere (Basel)., 10, 440, https://doi.org/10.3390/atmos10080440, 2019.

Miguel, A. G., Taylor, P. E., House, J., Glovsky, M. M., and Flagan, R. C.: Meteorological Influences on Respirable Fragment Release from Chinese Elm Pollen, Aerosol Sci. Technol., 40, 690-696, https://doi.org/10.1080/02786820600798869, 2006.

Mitchell, A. L., Scheremetjew, M., Denise, H., Potter, S., Tarkowska, A., Qureshi, M., Salazar, G. A., Pesseat, S., Boland, M. A., Hunter, F. M., Ten Hoopen, P., Alako, B., Amid, C., Wilkinson, D. J., Curtis, T. P., Cochrane, G., and Finn, R. D.: EBI Metagenomics in 2017: Enriching the analysis of microbial communities, from sequence reads to assemblies, Nucleic Acids Res., 46, D726-D735, https://doi.org/10.1093/nar/gkx967, 2018.

Möhler, O., DeMott, P. J., Vali, G., and Levin, Z.: Microbiology and atmospheric processes: the role of biological particles in cloud physics, Biogeosciences Discuss., 4, 2559-2591, https://doi.org/10.5194/bgd-4-2559-2007, 2007.

Morris, C. E., Sands, D. C., Glaux, C., Samsatly, J., Asaad, S., Moukahel, A. R., Gonçalves, F. L. T., and Bigg, E. K.: Urediospores of rust fungi are ice nucleation active at $>-10{ }^{\circ} \mathrm{C}$ and harbor ice nucleation active bacteria, Atmos. Chem. Phys., 13, 4223-4233, https://doi.org/10.5194/acp-13-4223-2013, 2013.

Morris, C. E., Soubeyrand, S., Bigg, E. K., Creamean, J. M., and Sands, D. C.: Mapping rainfall feedback to reveal the potential sensitivity of precipitation to biological aerosols, Bull. Am. Meteorol. Soc., 98, 1109-1118, https://doi.org/10.1175/BAMS-D-15-00293.1, 2017.

Morris, C. E. C., Conen, F., Huffman, J., Phillips, V., Pöschl, U., Sands, D. C. D., Alex Huffman, J., Phillips, V., Pöschl, U., and Sands, D. C. D.: Bioprecipitation: a feedback cycle linking Earth history, ecosystem dynamics and land use through biological ice nucleators in the atmosphere., Glob. Chang. Biol., 20, 341-351, https://doi.org/10.1111/gcb.12447, 2014.

Müller-Germann, I., Pickersgill, D. A., Paulsen, H., Alberternst, B., Pöschl, U., Fröhlich-Nowoisky, J., and Després, V. R.: Allergenic Asteraceae in air particulate matter: quantitative DNA analysis of mugwort and ragweed, Aerobiologia (Bologna)., 33, 493-506, https://doi.org/10.1007/s10453-017-9485-3, 2017.

Nkem, J. N., Wall, D. H., Virginia, R. A., Barrett, J. E., Broos, E. J., Porazinska, D. L., and Adams, B. J.: Wind dispersal of soil invertebrates in the McMurdo Dry Valleys, Antarctica, Polar Biol., 29, 346-352, https://doi.org/10.1007/s00300-005-0061-x, 2006.

Oren, A.: Taxonomy of halophilic Archaea: current status and future challenges, Extremophiles, 18, 825-834, https://doi.org/10.1007/s00792-014-0654-9, 2014.

O’Sullivan, D., Murray, B. J., Ross, J. F., and Webb, M. E.: The adsorption of fungal ice-nucleating proteins on mineral dusts: A terrestrial reservoir of atmospheric ice-nucleating particles, Atmos. Chem. Phys., 16, 7879-7887, https://doi.org/10.5194/acp-16-7879-2016, 2016. 
https://doi.org/10.5194/bg-2021-187

Preprint. Discussion started: 9 August 2021

(c) Author(s) 2021. CC BY 4.0 License.

(c) (i)

Ozturk, M., Guvensen, A., Gucel, S., and Altay, V.: An overview of the atmospheric pollen in Turkey and the Northern Cyprus, Pakistan J. Bot., 45, 191-195, 2013.

Pearce, D. A., Hughes, K. A., Lachlan-Cope, T., Harangozo, S. A., and Jones, A. E.: Biodiversity of air-borne microorganisms at Halley station, Antarctica, Extremophiles, 14, 145-159, https://doi.org/10.1007/s00792-009-0293-8, 2010.

Perryman, S. A., Clark, S. J., and West, J. S.: Splash dispersal of Phyllosticta citricarpa conidia from infected citrus fruit, Sci. Rep., 4, 1-8, https://doi.org/10.1038/srep06568, 2014.

Peter, H., Hörtnagl, P., Reche, I., and Sommaruga, R.: Bacterial diversity and composition during rain events with and without Saharan dust influence reaching a high mountain lake in the Alps, Environ. Microbiol. Rep., 6, 618-624, https://doi.org/10.1111/1758-2229.12175, 2014.

Pöhlker, C., Wiedemann, K. T., Sinha, B., Shiraiwa, M., Gunthe, S. S., Smith, M., Su, H., Artaxo, P., Chen, Q., Cheng, Y., Elbert, W., Gilles, M. K., Kilcoyne, A. L. D., Moffet, R. C., Weigand, M., Martin, S. T., Pöschl, U., and Andreae, M. O.: Biogenic potassium salt particles as seeds for secondary organic aerosol in the Amazon., Science, 337, 1075-1078, https://doi.org/10.1126/science.1223264, 2012.

Pöhlker, M. L., Krüger, O. O., Förster, J.-D., Berkemeier, T., Elbert, W., Fröhlich-Nowoisky, J., Pöschl, U., Pöhlker, C., Bagheri, G., Bodenschatz, E., Huffman, J. A., Scheithauer, S., and Mikhailov, E.: Respiratory aerosols and droplets in the transmission of infectious diseases, arXiv Prepr., http://arxiv.org/abs/2103.01188, 2021.

Polymenakou, P. N., Mandalakis, M., Stephanou, E. G., and Tselepides, A.: Particle size distribution of airborne microorganisms and pathogens during an intense African dust event in the eastern Mediterranean, Environ. Health Perspect., 116, 292-296, https://doi.org/10.1289/ehp.10684, 2008.

Pöschl, U. and Shiraiwa, M.: Multiphase Chemistry at the Atmosphere-Biosphere Interface Influencing Climate and Public Health in the Anthropocene, Chem. Rev., 115, 4440-4475, https://doi.org/10.1021/cr500487s, 2015.

Pöschl, U., Martin, S. T., Sinha, B., Chen, Q., Gunthe, S. S., Huffman, J. A., Borrmann, S., Farmer, D. K., Garland, R. M., Helas, G., Jimenez, J. L., King, S. M., Manzi, A., Mikhailov, E., Pauliquevis, T., Petters, M. D., Prenni, A. J., Roldin, P., Rose, D., Schneider, J., Su, H., Zorn, S. R., Artaxo, P., and Andreae, M. O.: Rainforest aerosols as biogenic nuclei of clouds and precipitation in the Amazon., Science, 329, 1513-1516, https://doi.org/10.1126/science.1191056, 2010.

Pouleur, S., Richard, C., Martin, J. G., and Antoun, H.: Ice Nucleation Activity in Fusarium acuminatum and Fusarium avenaceum., Appl.

Environ. Microbiol., 58, 2960-2964, https://doi.org/10.1128/AEM.58.9.2960-2964.1992, 1992.

Pranesha, T. S. and Kamra, A. K.: Scavenging of aerosol particles by large water drops: 3. Washout coefficients, half-lives, and rainfall depths, J. Geophys. Res. Atmos., 102, 23 947-23 953, https://doi.org/10.1029/97jd01835, 1997.

Prenni, A. J., Tobo, Y., Garcia, E., DeMott, P. J., Huffman, J. A., McCluskey, C. S., Kreidenweis, S. M., Prenni, J. E., Pöhlker, C., and Pöschl, U.: The impact of rain on ice nuclei populations at a forested site in Colorado, Geophys. Res. Lett., 40, 227-231, https://doi.org/10.1029/2012GL053953, 2013.

Ptatscheck, C., Gansfort, B., and Traunspurger, W.: The extent of wind-mediated dispersal of small metazoans, focusing nematodes, Sci. Rep., 8, 6814, https://doi.org/10.1038/s41598-018-24747-8, 2018.

Puls, K. E. and Von Wahl, P. G.: Zum einfluß von niederschlägen auf pollen in der atmosphäre, Grana, 30, 235-241, https://doi.org/10.1080/00173139109427804, 1991

Pummer, B. G., Bauer, H., Bernardi, J., Bleicher, S., and Grothe, H.: Suspendable macromolecules are responsible for ice nucleation activity of birch and conifer pollen, Atmos. Chem. Phys., 12, 2541-2550, https://doi.org/10.5194/acp-12-2541-2012, 2012. 
https://doi.org/10.5194/bg-2021-187

Preprint. Discussion started: 9 August 2021

(c) Author(s) 2021. CC BY 4.0 License.

(c) (i)

Pummer, B. G., Atanasova, L., Bauer, H., Bernardi, J., Druzhinina, I. S., and Grothe, H.: Spores of most common airborne fungi reveal no ice nucleation activity, Biogeosciences Discuss., 10, 10 125-10 141, https://doi.org/10.5194/bgd-10-10125-2013, 2013.

Pummer, B. G., Budke, C., Augustin-Bauditz, S., Niedermeier, D., Felgitsch, L., Kampf, C. J., Huber, R. G., Liedl, K. R., Loerting, T., Moschen, T., Schauperl, M., Tollinger, M., Morris, C. E., Wex, H., Grothe, H., Pöschl, U., Koop, T., and Fröhlich-Nowoisky, J.: Ice nucleation by water-soluble macromolecules, Atmos. Chem. Phys., 15, 4077-4091, http://www.atmos-chem-phys.net/15/4077/2015/ acp-15-4077-2015.htmlhttp://www.atmos-chem-phys-discuss.net/14/24273/2014/acpd-14-24273-2014.html, 2015.

Quast, C., Pruesse, E., Yilmaz, P., Gerken, J., Schweer, T., Yarza, P., Peplies, J., and Glöckner, F. O.: The SILVA ribosomal RNA gene database project: Improved data processing and web-based tools, Nucleic Acids Res., 41, 590-596, https://doi.org/10.1093/nar/gks1219, 2013.

R-Development-Core-Team: R: A language and environment for statistical computing, R Foundation for Statistical Computing, https://www. r-project.org, 2011.

Rathnayake, C. M., Metwali, N., Jayarathne, T., Kettler, J., Huang, Y., Thorne, P. S., O‘apos;Shaughnessy, P. T., and Stone, E. A.: Influence of rain on the abundance of bioaerosols in fine and coarse particles, Atmos. Chem. Phys., 17, 2459-2475, http://www.atmos-chem-phys. net/17/2459/2017/, 2017.

Reche, I., D’Orta, G., Mladenov, N., Winget, D. M., and Suttle, C. A.: Deposition rates of viruses and bacteria above the atmospheric boundary layer, ISME J., 12, 1154-1162, https://doi.org/10.1038/s41396-017-0042-4, 2018.

Ribeiro, H., Cunha, M., and Abreu, I.: Airborne pollen concentration in the region of Braga, Portugal, and its relationship with meteorological parameters, Aerobiologia (Bologna)., 19, 21-27, https://doi.org/10.1023/A:1022620431167, 2003.

Richard, C., Martin, J.-G., and Pouleur, S.: Ice nucleation activity identified in some phytopathogenic Fusarium species, Phytoprotection, 77, 83-92, https://doi.org/10.7202/706104ar, 1996.

Rittenour, W. R., Hamilton, R. G., Beezhold, D. H., and Green, B. J.: Immunologic, spectrophotometric and nucleic acid based methods for the detection and quantification of airborne pollen, J. Immunol. Methods, 383, 47-53, https://doi.org/10.1016/j.jim.2012.01.012, 2012.

Robertson, C. E., Baumgartner, L. K., Harris, J. K., Peterson, K. L., Stevens, M. J., Frank, D. N., and Pace, N. R.: Cultureindependent analysis of aerosol microbiology in a metropolitan subway system, Appl. Environ. Microbiol., 79, 3485-3493, https://doi.org/10.1128/AEM.00331-13, 2013.

Rodriguez-Caballero, E., Belnap, J., Büdel, B., Crutzen, P. J., Andreae, M. O., Pöschl, U., and Weber, B.: Dryland photoautotrophic soil surface communities endangered by global change, Nat. Geosci., 11, 185-189, https://doi.org/10.1038/s41561-018-0072-1, 2018.

Sakallah, S. A., Lanning, R. W., and Cooper, D. L.: DNA fingerprinting of crude bacterial lysates using degenerate RAPD primers, PCR Methods Appl., 4, 265-268, https://doi.org/10.1101/gr.4.5.265, 1995.

Sands, D., Langhans, V., Scharen, A., and De Smet, G.: The association between bacteria and rain and possible resultant meteorological implications., Idojaras, 86, 148-151, http://agris.fao.org/agris-search/search.do?recordID=HU19830870326, 1982.

Šantl-Temkiv, T., Sahyoun, M., Finster, K., Hartmann, S., Augustin, S., Stratmann, F., Wex, H., Clauss, T., Nielsen, N. W., Sørensen, J. H., Korsholm, U. S., Wick, L. Y., and Karlson, U. G.: Characterization of airborne ice-nucleation-active bacteria and bacterial fragments, Atmos. Environ., 109, 105-117, https://doi.org/10.1016/j.atmosenv.2015.02.060, 2015.

Schnell, R. C. and Vali, G.: Biogenic ice nuclei: Part I. Terrestrial and marine sources, J. Atmos. Sci., 33, 1554-1564, https://doi.org/10.1175/1520-0469(1976)033<1554:BINPIT>2.0.CO;2, 1976. 
https://doi.org/10.5194/bg-2021-187

Preprint. Discussion started: 9 August 2021

(c) Author(s) 2021. CC BY 4.0 License.

(c) (i)

Schrod, J., Weber, D., Drücke, J., Keleshis, C., Pikridas, M., Ebert, M., Cvetković, B., Nickovic, S., Marinou, E., Baars, H., Ansmann, A., Vrekoussis, M., Mihalopoulos, N., Sciare, J., Curtius, J., and Bingemer, H. G.: Ice nucleating particles over the Eastern Mediterranean measured by unmanned aircraft systems, Atmos. Chem. Phys., 17, 4817-4835, https://doi.org/10.5194/acp-17-4817-2017, 2017.

Schumacher, C. J., Pöhlker, C., Aalto, P., Hiltunen, V., Petäjä, T., Kulmala, M., Pöschl, U., and Huffman, J. A.: Seasonal cycles of fluorescent biological aerosol particles in boreal and semi-arid forests of Finland and Colorado, Atmos. Chem. Phys., 13, 11987-12001, https://doi.org/10.5194/acp-13-11987-2013, 2013.

Seesao, Y., Gay, M., Merlin, S., Viscogliosi, E., Aliouat-Denis, C. M., and Audebert, C.: A review of methods for nematode identification, J.

Microbiol. Methods, 138, 37-49, https://doi.org/10.1016/j.mimet.2016.05.030, 2017.

Seinfeld, J. H. and Pandis, S. N.: Atmospheric chemistry and physics: from air pollution to climate change, John Wiley \& Sons, Inc., 3 edn., 2016.

Shaffer, B. and Lighthart, B.: Survey of Culturable Airborne Bacteria at Four Diverse Locations in Oregon: Urban, Rural, Forest, and Coastal, Microb. Ecol., 34, 167-177, https://doi.org/10.1007/s002489900046, 1997.

Shikov, E. V. and Vinogradov, A. A.: Dispersal of terrestrial gastropods by birds during the nesting period, Folia Malacol., 21, 105-110, https://doi.org/10.12657/folmal.021.012, 2013.

Smets, W., Moretti, S., Denys, S., and Lebeer, S.: Airborne bacteria in the atmosphere: Presence, purpose, and potential, Atmos. Environ., 139, 214-221, https://doi.org/10.1016/j.atmosenv.2016.05.038, 2016.

Smith, D. J., Timonen, H. J., Jaffe, D. A., Griffin, D. W., Birmele, M. N., Perry, K. D., Ward, P. D., and Roberts, M. S.: Intercontinental dispersal of bacteria and archaea by transpacific winds., Appl. Environ. Microbiol., 79, 1134-1139, https://doi.org/10.1128/AEM.0302912, 2013.

Söllinger, A. and Urich, T.: Methylotrophic methanogens everywhere — physiology and ecology of novel players in global methane cycling, Biochem. Soc. Trans., 47, 1895-1907, https://doi.org/10.1042/BST20180565, 2019.

Steiner, A. L., Brooks, S. D., Deng, C., Thornton, D. C. O., Pendleton, M. W., and Bryant, V.: Pollen as atmospheric cloud condensation nuclei, Geophys. Res. Lett., 42, 3596-3602, https://doi.org/10.1002/2015GL064060, 2015.

Taylor, P., Flagan, R., Miguel, A., Valenta, R., and Glovsky, M.: Birch pollen rupture and the release of aerosols of respirable allergens., Clin. Exp. Allergy, 34, 1591-1596, https://doi.org/10.1111/j.1365-2222.2004.02078.x, 2004.

Taylor, P. E. and Jonsson, H.: Thunderstorm asthma, Curr. Allergy Asthma Rep., 4, 409-413, https://doi.org/10.1007/s11882-004-0092-3, 2004.

Taylor, P. E., Flagan, R. C., Valenta, R., and Glovsky, M. M.: Release of allergens as respirable aerosols: A link between grass pollen and asthma, J. Allergy Clin. Immunol., 109, 51-56, https://doi.org/10.1067/mai.2002.120759, 2002.

Tobo, Y., Prenni, A. J., DeMott, P. J., Huffman, J. A., McCluskey, C. S., Tian, G., Pöhlker, C., Pöschl, U., and Kreidenweis, S. M.: Biological aerosol particles as a key determinant of ice nuclei populations in a forest ecosystem, J. Geophys. Res. Atmos., 118, 10,100-10,110, https://doi.org/10.1002/jgrd.50801, 2013.

Tong, Y. and Lighthart, B.: The annual bacterial particle concentration and size distribution in the ambient atmosphere in a rural area of the Willamette Valley, Oregon, Aerosol Sci. Technol., 32, 393-403, https://doi.org/10.1080/027868200303533, 2000.

Vali, G.: Quantitative Evaluation of Experimental Results an the Heterogeneous Freezing Nucleation of Supercooled Liquids, https://doi.org/10.1175/1520-0469(1971)028<0402:QEOERA>2.0.CO;2, 1971.

Vanschoenwinkel, B., Gielen, S., Seaman, M., and Brendonck, L.: Any way the wind blows - frequent wind dispersal drives species sorting in ephemeral aquatic communities, Oikos, 117, 125-134, https://doi.org/10.1111/j.2007.0030-1299.16349.x, 2008. 
https://doi.org/10.5194/bg-2021-187

Preprint. Discussion started: 9 August 2021

(c) Author(s) 2021. CC BY 4.0 License.

(c) (1)

Wehking, J., Pickersgill, D. A., Bowers, R. M., Teschner, D., Pöschl, U., Fröhlich-Nowoisky, J., and Després, V. R.: Community composition and seasonal changes of archaea in coarse and fine air particulate matter, Biogeosciences, 15, 4205-4214, https://doi.org/10.5194/bg-154205-2018, 2018.

Whon, T. W., Kim, M.-S., Roh, S. W., Shin, N.-R., Lee, H.-W., and Bae, J.-W.: Metagenomic characterization of airborne viral DNA diversity in the near-surface atmosphere., J. Virol., 86, 8221-8231, https://doi.org/10.1128/JVI.00293-12, 2012.

Wilson, T. W., Ladino, L. A., Alpert, P. A., Breckels, M. N., Brooks, I. M., Browse, J., Burrows, S. M., Carslaw, K. S., Huffman, J. A., Judd, C., Kilthau, W. P., Mason, R. H., McFiggans, G., Miller, L. A., Nájera, J. J., Polishchuk, E., Rae, S., Schiller, C. L., Si, M., Temprado, J. V., Whale, T. F., Wong, J. P. S., Wurl, O., Yakobi-Hancock, J. D., Abbatt, J. P. D., Aller, J. Y., Bertram, A. K., Knopf, D. A., and Murray, B. J.: A marine biogenic source of atmospheric ice-nucleating particles, Nature, 525, 234-238, https://doi.org/10.1038/nature14986, 2015.

Wolf, M., Twaroch, T. E., Huber, S., Reithofer, M., Steiner, M., Aglas, L., Hauser, M., Aloisi, I., Asam, C., Hofer, H., Parigiani, M. A., Ebner, C., Bohle, B., Briza, P., Neubauer, A., Stolz, F., Jahn-Schmid, B., Wallner, M., and Ferreira, F.: Amb a 1 isoforms: Unequal siblings with distinct immunological features, Allergy Eur. J. Allergy Clin. Immunol., 72, 1874-1882, https://doi.org/10.1111/all.13196, 2017.

Wright, T. P., Hader, J. D., McMeeking, G. R., and Petters, M. D.: High relative humidity as a trigger for widespread release of ice nuclei, Aerosol Sci. Technol., 48, i-v, https://doi.org/10.1080/02786826.2014.968244, 2014.

740 Yahya, R. Z., Arrieta, J. M., Cusack, M., and Duarte, C. M.: Airborne Prokaryote and Virus Abundance Over the Red Sea, Front. Microbiol., 10, 1-10, https://doi.org/10.3389/fmicb.2019.01112, 2019.

Yooseph, S., Andrews-Pfannkoch, C., Tenney, A., McQuaid, J., Williamson, S., Thiagarajan, M., Brami, D., Zeigler-Allen, L., Hoffman, J., Goll, J. B., Fadrosh, D., Glass, J., Adams, M. D., Friedman, R., and Venter, J. C.: A metagenomic framework for the study of airborne microbial communities, PLoS One, 8, e81 862, https://doi.org/10.1371/journal.pone.0081862, 2013.

Zhen, Q., Deng, Y., Wang, Y., Wang, X., Zhang, H., Sun, X., and Ouyang, Z.: Meteorological factors had more impact on airborne bacterial communities than air pollutants, Sci. Total Environ., 601-602, 703-712, https://doi.org/10.1016/j.scitotenv.2017.05.049, 2017.

Zoberi, M.: Effect of temperature and humidity on ballistospore discharge, Trans. Br. Mycol. Soc., 47, 109-114, https://doi.org/10.1016/s0007-1536(64)80085-1, 1964. 